Recreation Management Support Program

\title{
Economic Impacts from Spending by Community Dock Owners at Rough River Lake
}

Kathleen Perales, Dennis B. Propst, Benoni L. Amsden, January 2008

Wen-Huei Chang, Richard Kasul, and LiChu Lee 


\section{Economic Impacts from Spending by Community Dock Owners at Rough River Lake}

Kathleen Perales, Wen-Huei Chang, Richard Kasul, and LiChu Lee

Environmental Laboratory

U.S. Army Engineer Research and Development Center

3909 Halls Ferry Road

Vicksburg, MS 39180-6199

Dennis B. Propst, Benoni L. Amsden

Michigan State University

115 Natural Resources Building

East Lansing, MI 48824

Final report

Approved for public release; distribution is unlimited. [or a restricted statement]

Prepared for U.S. Army Corps of Engineers

Washington, DC 20314-1000 


\begin{abstract}
This report documents the local economic impacts of users of community-owned docks at Rough River Lake, located in western Kentucky. This economic assessment is based on the results of a 1999 survey of a sample of Rough River Lake community dock owners. Spending estimates are adjusted to 2004 dollars. The economic impacts estimated for Rough River Lake are useful for accountability purposes, lake support, and explaining the role of the lake in the region's economy. This report demonstrates how the survey results can be used to evaluate management alternatives and strategies and to conduct sensitivity analyses.
\end{abstract}

DISCLAIMER: The contents of this report are not to be used for advertising, publication, or promotional purposes. Citation of trade names does not constitute an official endorsement or approval of the use of such commercial products. All product names and trademarks cited are the property of their respective owners. The findings of this report are not to be construed as an official Department of the Army position unless so designated by other authorized documents. 


\section{Contents}

Figures and Tables................................................................................................................

Summary

Preface ............................................................................................................................................................viii

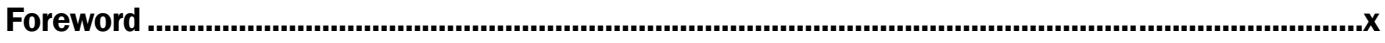

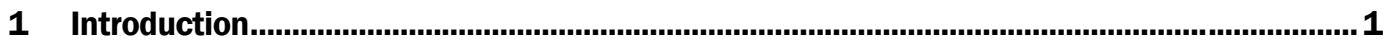

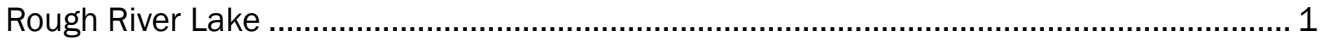

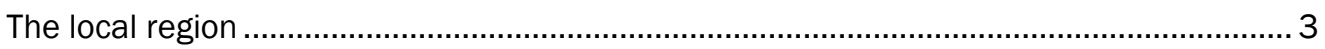

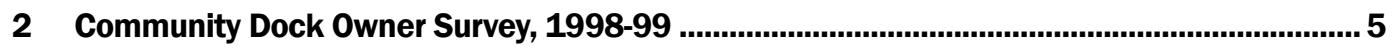

3 Results

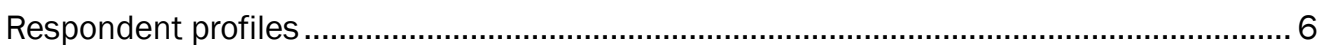

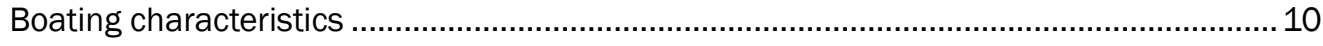

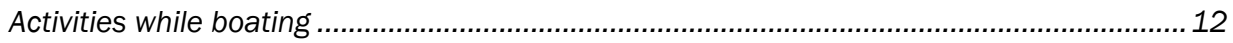

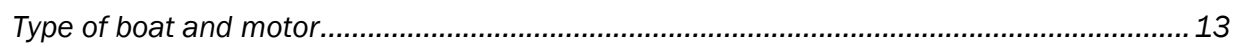

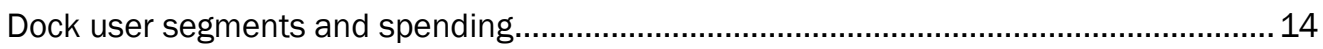

Average spending for full sample of community dock owners ........................................ 14

Average spending by segment: Day use versus overnight .............................................. 17

Average spending by boat length segments.................................................................... 19

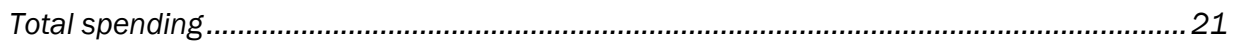

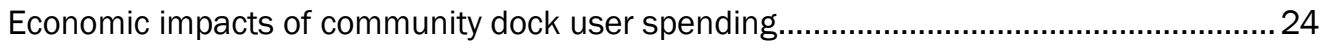

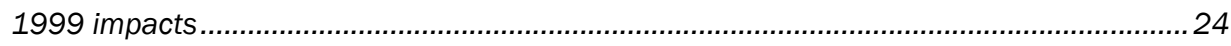

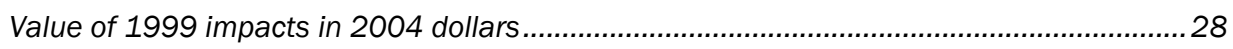

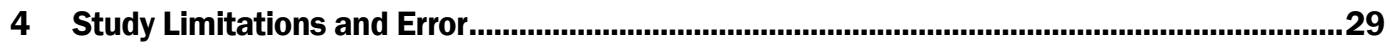

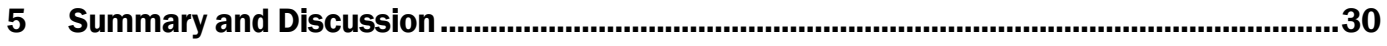

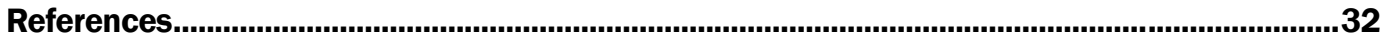

\section{Report Documentation Page}




\section{Figures and Tables}

\section{Figures}

Figure 1. Rough River Lake and the surrounding region.

Figure 2. Gender of community dock owners at Rough River Lake, 1999 (N=396)......................... 6

Figure 3. Age of community dock owners at Rough River lake, 1999 (N=389)............................ 7

Figure 4. Education of community dock owners at Rough River Lake, 1999 (N=392).................... 7

Figure 5. Race of community dock owners at Rough River Lake, 1999 (N=394) (about 1 percent were Hispanic or of Latino origin). ...................................................................

Figure 6. Surveys conducted with registered boat owners at Rough River Lake community docks, $1999(\mathrm{~N}=395)$.

Figure 7. Household income of community dock owners at Rough River Lake, 1999 $(\mathrm{N}=338)$.

Figure 8. Household size of community dock owners at Rough River Lake, 1999 (N=390).

Figure 9. Number of people under 18 in households of community dock owners at Rough River Lake, 1999 (N=395)

Figure 10. Permanent residence of community dock owners at Rough River Lake, 1999 $(\mathrm{N}=396)$.

Figure 11. Seasonal home ownership of community dock owners at Rough River Lake, $1999(\mathrm{~N}=396)$.

Figure 12. Number of boating trips made by community dock owners last year compared to previous three-year average at Rough River Lake, 1999 (N=371).

Figure 13. "What other activities did you or others participate in during your boating trips last year that I have not already mentioned?" (from Rough River Lake Community Docks, 1999, N=367).

Figure 14. Expenditures by community dock owners/users on most recent trip compared to similar trips in the last 12 months at Rough River Lake, 1999 ( $\mathrm{N}=385)$.

\section{Tables}

Table 1. Summary of recreation visits to Rough River Lake, 1999............................................. 3

Table 2. Economic activity in the Rough River Lake Region, 2000 ................................................. 4

Table 3. Number of trips to Rough River Lake community boat docks the previous year (09/01/1998 to 08/31/1999)

Table 4. Recreation activity participation during previous year's trips to Rough River Lake community boat docks (09/01/1998 to 08/31/1999).

Table 5. Boat type and length cross-tabulation, Rough River Lake community dock owner survey, 1999 ( $N=372)$.

Table 6. Boat type and motor cross-tabulation, Rough River Lake community dock owner survey, $1999(\mathrm{~N}=366)$ 
Table 7. Boat length and motor cross-tabulation, Rough River Lake community dock owner survey, $1999(\mathrm{~N}=355)$.

Table 8. Summary of Rough River Lake community dock owners'/users' spending and use profiles, 09/1998 to 08/1999 (spending per party trip).

Table 9. Spending and use by length of stay segments, Rough River Lake community dock owner survey, 09/1998 to 08/1999 (spending per party trip).

Table 10. Spending and use by boat length segments, Rough River Lake community dock owner survey, 09/1998 to 08/1999 (spending per party trip).

Table 11. Total annual use figures for community dock owner survey at Rough River Lake (1999)

Table 12. Total trip spending in local area by Rough River Lake community dock owners/users (1999).

Table 13. Total trip spending by Rough River Lake community dock owners/users (1999)

Table 14. Total spending on fixed, annual goods and services by community dock owners at Rough River Lake (1999).

Table 15. Regional economic impacts of Rough River Lake community dock owners'/users' trip spending (1999, for trip spending within 30 miles only).

Table 16. Regional economic impacts of Rough River Lake community dock owners' durable goods and annual spending (1999).

Table 17. Regional economic impacts of Rough River Lake community dock owners'/users' trip and owners' annual spending (in 2004 dollars, for spending within 30 miles only).

Table 18. Direct impacts of an additional 1,000 community dock owner party trips by segment, Rough River Lake. 


\section{Summary}

This report documents the local economic impacts of owners and guests of community-owned docks at Rough River Lake, located in western Kentucky and situated within the U.S. Army Corps of Engineers District, Louisville. This economic assessment is based on the results of a 1999 survey of a sample of Rough River Lake dock owners. Results are adjusted to 2004 dollars.

Built for flood control, at summer pool, Rough River Lake encompasses 5,100 surface acres and has 220 miles of shoreline miles. Rough River Lake provides opportunities for both recreation and management of fish, wildlife, and water quality. Located in close proximity is a 6,000 acre State Wildlife Management Area, and Mammoth Cave National Park, the largest cave system in the world. Total tourism activity in the six-county region surrounding Rough River Lake is \$163 million, or 1.7 percent of all economic activity in that region.

Access to large bodies of water and their related resources, including scenic views, makes Corps of Engineers lakes desirable for private residential areas and their associated community-owned docks. The Corps of Engineers permitted 385 community-owned docks at Rough River Lake in 1999. The estimated 44,063 party trips taken by community dock owners/ users in 1999 accounted for 6.6 percent of total recreation usage at the lake.

In 1999, owners/ users of community-owned docks spent significant amounts of money in the local area, including $\$ 6.7$ million on trip-related items (gasoline, meals, lodging, etc.) and \$1.1 million on new boats, dock maintenance, insurance, and other annual services. Together, this $\$ 7.8$ million in spending in the six-county region surrounding Rough River Lake provides the economic base for $\$ 4.1$ million in direct sales, $\$ 1.4$ million in direct personal income (wages and salaries) for local residents, and 85 jobs in tourism-related businesses. The $\$ 4.1$ million in direct sales is about 2.6 percent of the total of all tourism activity (\$163 million) (sales have been price inflated for this computation). In 2004 dollars, these figures become $\$ 8.1$ million in trip-related expenditures and $\$ 1.3$ million in new boats and annual expenses. The 
added economic effects - in 2004 dollars - are $\$ 5$ million in direct sales and $\$ 1.7$ million in direct personal income.

The figures above are direct effects only of the $\$ 7.8$ million in dock owner/ user spending in 1999. Another \$1.5 million in sales ( $\$ 1.9$ million in sales in 2004 dollars) is generated through secondary effects, as dock owner/ user spending circulates through the local economy. While the direct effects accrue primarily to the retail trade sector, restaurants, manufacturing (mainly because of the purchases of new boats locally), and services, secondary effects benefit a wide range of local businesses. The tourism sales multiplier for the region is 1.37 , indicating $\$ 0.37$ in secondary sales for every dollar of direct sales.

Visitor segmentation is useful for planning purposes. This report provides results for the full sample of community dock owners/ users and for dock owner segments that are useful for planning purposes: day use versus overnight stay dock owners, and dock owners in three boat size classes. Day users comprised 27 percent of the sample of community dock users, while 73 percent spent at least one night in the area on their last trip. In terms of total spending in the local region, day users of community docks contributed 26 percent and overnight stay dock users, 74 percent. Nearly 55 percent of the sample had small-sized boats ( $20 \mathrm{ft}$ and smaller), while 44 percent were medium ( 21 to $30 \mathrm{ft}$ ) and less than 1 percent were large (above $30 \mathrm{ft}$ ). Dock users with small length boats contributed 59 percent of total spending locally, and those with medium-size boats contributed 41 percent.

The economic impacts estimated for Rough River Lake are useful for accountability purposes, lake support, and explaining the role of the lake in the region's economy. This report demonstrates how the survey results can also be used to evaluate management alternatives and strategies and to conduct sensitivity analyses. 


\section{Preface}

The work reported herein was undertaken for the "Measuring the Economic Effects of Boat Dock Permit and Marina Slip Holders" work unit of the Recreation Management Support Program (RMSP). The RMSP is funded by the Operations and Maintenance (O\&M) General Appropriation and encompasses activities previously conducted through the Recreation Research Program and the Natural Resources Technical Support Program. The U.S. Army Engineer Research and Development Center (ERDC) provides program management support for execution of approved RMSP activities. The RMSP is managed at ERDC by Scott J ackson, Environmental Laboratory (EL). Kathleen Perales has served as Principal Investigator of the work unit since its creation in 1995.

This report documents a joint effort between ERDC and Michigan State University under contract with the United States Department of Agriculture to conduct lake level investigations on the economic spending patterns of visitors to communities, private boat docks, and marinas on Corps of Engineers water resources projects.

A Recreation Leadership Advisory Team (RLAT) provides oversight for the RMSP. The team has representatives from each Major Subordinate Command/Regional Office within the Corps of Engineers. In addition, four district offices and four project offices are represented. Donald Dunwoody, RLAT representative from the Northwestern Division, served as proponent for this work unit.

This report was prepared by Benoni Amsden and Dr. Dennis Propst of Michigan State University under USDA contract. Dr. Wen-Huei Chang, ERDC, performed all economic impact analyses. Dr. LiChu Lee, ERDC, served to verify all data elements. Richard Kasul, ERDC, and Kathleen Perales, ERDC, were responsible for the design, instrumentation, sampling frame, and contract oversight. This work was conducted under the general supervision of Scott J ackson, Acting Chief, Ecological Resources Branch (ERB); Dr. David Tazik, Chief, Ecosystem Evaluation and Engineering Division (EEED); and Dr. Beth Fleming, Director, EL.

Peer Reviewers of this report were Dr. Bonnie Bryson, Research Biologist, ERDC, and Mark Wilmes, Supervisory Park Ranger, Rough River Lake, USACE. 
COL Richard B. J enkins was Commander and Executive Director of ERDC. Dr. J ames R. Houston was Director. 


\section{Foreword}

This report represents one of nine market segmentation studies conducted at Corps of Engineer (Corps) water resources projects (lakes). The economic impact studies were conducted in 1999 and the information has been converted to 2004 dollars. It should be noted that no single study provides a complete portrait of any lake's boating market. The studies were limited to three market segments, marina slip renters, private dock, and community dock owners. These three groups do not reflect the spectrum of boating usage or market segments at any one of the lakes studied. The primary purpose of the studies was to obtain an understanding of these three market segments.

In addition to recreation usage, each of these segments is handled under different real estate instruments or shoreline use permit instruments. Marina slips (one boat per slip) are handled by the Corps through a lease agreement with the marina operator. Individual marina operators (lease holders) were involved in the development of contact lists for individual slip renters. Private dock owners (one dock permit, one household, potentially multiple boats) have a direct shoreline-use permit with the Corps and pay a fee. Community docks (one dock permit, multiple households, one boat per slip, a single household may hold multiple slips) are not tied to a single household but to a group of homes within a community. This permit type has a single point of contact (e.g. homeowner association). Typically the fee for a private or community dock permit is between $\$ 30$ and $\$ 35$ for 5 years. Additional administrative fees may also be collected to recover the actual cost of administration inspections and processing of permits. The cost is variable.

The lakes and market segments studied were:

- Table Rock Lake, community dock

- Rough River Lake, community dock

- Pomme de Terre Lake, community dock

- Harry S. Truman Dam and Reservoir, marina

- Raystown Lake, marina

- Hartwell Lake, private dock 
- Lake Barkley, private dock

- Lake Sidney Lanier, private dock and marina

Each of the lakes studied has a variety of boating and water usage issues that were not a part of this economic impact evaluation. This economic impact assessed recreation visitor trip spending and annual durable goods-related expenditures. In order to provide managers with a tool to assess the effects of management, this report outlined the spending categories of boat owners and visitors associated with the recreational trip under study. Examples are provided illustrating changes in the number of boat trips and the changes that could be seen in economic impacts. These are provided as illustrations. The same illustration can be used by managers to help assess low water conditions and boating trips lost, to get a sense of the change in economic impacts. This study did not include the impacts of additional boats over time to determine changes in use, water quality, social or environmental impacts or the like. This study did not include the changes in use based on the increases in gasoline prices or technological changes in boating products. These are elements outside the study parameters and would serve as useful points of departure for further research. These reports should be evaluated in part with the larger boating usage that occurs at the individual lake and the changes that have occurred over time (including expenditure changes such as the increasing cost of gasoline). They serve in part to document a baseline, which in part justifies publication at this late date.

For example, at a single lake, boating utilization should be evaluated within a larger context of the multipurpose mission of each of the lakes. To get an understanding of historical use and issues at Corps of Engineers facilities, the following documents have been recommended for further study: national and state regulations, project master-planning documents, shoreline management plans, environmental assessments, and other local studies. Consult the local project manager for an assessment of other documents that should be considered in addition to the ones provided. 


\section{Introduction}

This report documents the local economic impacts of users of communityowned docks ${ }^{1}$ at Rough River Lake, located in western Kentucky. These estimates are then adjusted to 2004 dollars. Economic impacts are measured as direct and secondary sales, income, and jobs in the local area resulting from spending by those who use community-owned docks. The economic estimates are produced using the Recreation Economic Assessment System (REAS) (Chang et al. 2001). Three major inputs to the model are:

- number of visits broken down into day use/ overnight segments and three boat size segments

- spending averages for each segment

- economic multipliers for the local region

Inputs are derived from results contained in this report, the Natural Resource Management System (NRMS) database (U.S. Army Corps of Engineers (USACE) 2006c), and IMPLAN input-output modeling software (Minnesota IMPLAN Group 1996). The REAS model (USACE 2006a) provides a spreadsheet template that combines dock user visitation data, spending, and regional multipliers to compute changes in sales, personal income, jobs, and value added in the region.

\section{Rough River Lake}

Built between 1955 and 1961 as part of a flood control plan for the Ohio River Basin, at summer pool, Rough River Lake encompasses 5,100 surface acres and has 220 miles of shoreline miles (Figure 1). Rough River Lake provides opportunities for both recreation and management of fish, wildlife, and water quality (USACE 2006b). Located in close proximity is a 6,000-acre State Wildlife Management Area, and Mammoth Cave National Park, the largest cave system in the world.

\footnotetext{
1 Community Docks: Community docks are privately owned, multi-slip facilities shared and used by several groups of people. These docks should be permitted under the authority of ER 1130-2-406 (USACE 1999). Do not include commercial docks or marinas.

Private Docks: A private dock is one that serves only one property owner. These docks should be permitted under the authority of ER 1130-2-406 (USACE 1999). Do not include commercial docks or marinas. (USACE 2006c).
} 


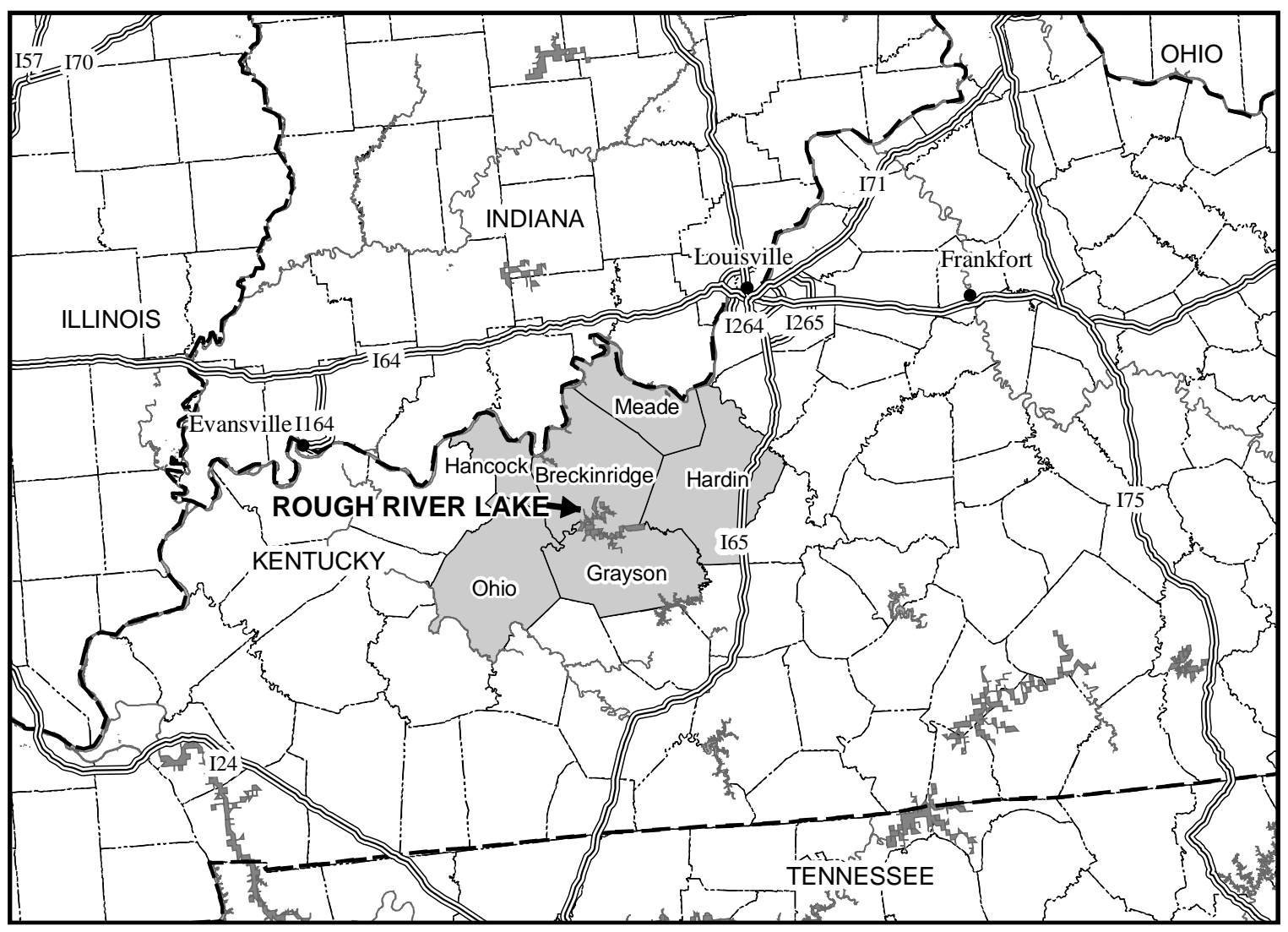

Figure 1. Rough River Lake and the surrounding region.

The Corps of Engineers operates four campgrounds, four boat ramps, and two swimming beaches on Rough River Lake. Additionally, the Kentucky State Parks Department operates the Rough River Lake State Resort Park, which features a 40-room lodge, dining room, cottages, 9-hole golf course, campground, airstrip, and 121-slip marina.

Rough River Lake hosted just over 2 million recreation visits in 1999, 96 percent of which were by day users (Table 1, top row). Non-boaters accounted for nearly 1.7 million day use visits, and boaters another 272,000. Since visitor spending and economic impacts in this report are based on party-days or nights, these figures are shown on the bottom row of Table 1. In 1999, there were roughly 797,000 party-days of recreation use.

The Corps of Engineers began permitting community-owned docks on Rough River Lake in 1976. Since 1999, over 385 community-owned docks have been permitted. A single community-owned dock permit on Rough River Lake allows for a structure that maintains a minimum of one slip and a maximum of 17 slips. The 2005 Shoreline Management Plan limits the maximum number of slips to 12 . Each boat in each slip must have a 
current state boating registration. Each of the permitted docks has a single point of contact for the group of slips in the dock. This point of contact was our initial point of reference when conducting these surveys.

Table 1. Summary of recreation visits to Rough River Lake, 1999.

\begin{tabular}{|c|c|c|c|c|c|c|c|}
\hline \multirow[b]{2}{*}{ Parameter } & \multicolumn{2}{|c|}{ Camper $^{1}$} & \multicolumn{2}{|c|}{ Day User² } & \multicolumn{2}{|c|}{ Other Overnight ${ }^{3}$} & \multirow[b]{2}{*}{ Total } \\
\hline & Boat & Non-Boat & Boat & Non-Boat & Boat & Non-Boat & \\
\hline $\begin{array}{l}\text { Visits (Person-Trips, } \\
1,000 \text { s) }\end{array}$ & 3.1 & 19.2 & 271.5 & $1,668.0$ & 8.1 & 50.0 & $2,020.1$ \\
\hline $\begin{array}{l}\text { Average Length of Stay } \\
\text { (Days) }\end{array}$ & 4.2 & 3.8 & - & - & 2.4 & 3.0 & - \\
\hline Average Party Size & 3.5 & 2.8 & 2.8 & 2.8 & 3.3 & 2.5 & - \\
\hline $\begin{array}{l}\text { Visits (Party-Days, } \\
1,000 \text { s) }\end{array}$ & 3.8 & 26.5 & 97.5 & 602.9 & 6.0 & 60.7 & 797.4 \\
\hline
\end{tabular}

1 Number of campers in party days was derived from the 1998 Natural Resource Management System (NRMS) (USACE 2006c), CUR_FEE database (the last year that camper revenue data is available) by dividing total camping revenue by an average of $\$ 8.00$ per party day camping fee and expanding by the number of non-Corps managed campsites. The number of camper party-days was then adjusted to 1999 by multiplying the ratio of 1999 visits to 1998 visits from the PR_USE database. Then, party-days were converted to person-trips by the following formula: Number of campers in person-trips = number of party-days times average party size $/$ average length of stay. Percent of boaters was obtained from the NRMS, PR_USE database. Party size and length of stay figures are based on the results of a national survey (Chang et al. 2003).

2 Number of day users in person-trips was derived from the 1999 NRMS (USACE 2006c), PR_USE database by subtracting camper visits from total visits. Then, number of day users in party-days $=$ number of person-trips times average length of stay / average party size. Percent of boaters was obtained from NRMS, PR_USE database.

${ }^{3}$ Assumes that 3 percent of day users stayed overnight in lodging accommodations outside of project boundaries.

\section{The local region}

Six counties in Kentucky (Breckinridge, Grayson, Hardin, Hancock, Meade and Ohio) comprise the local economic impact study region for Rough River Lake. According to the U.S. Census Bureau (2006), the population of this area is 194,532 (2000) or 200,562 (2004 estimate). The average median household income of these counties is $\$ 33,229$ (1999), compared to the statewide median of $\$ 33,672$ (1999).

The Manufacturing and Government sectors are the principal economic base of the area, combining to account for 49 percent of sales, 41 percent of jobs, and 61 percent of employee wages in the six-county region (Table 2). 
Total tourism sales in the local region are estimated at \$163 million (Table 2: 100 percent of hotel/ motel +100 percent of amusement \& recreation +25 percent of restaurant +25 percent of retail sales). Thus, tourism accounts for 4-5 percent of jobs in the region and 1-2 percent of sales. ${ }^{1}$ In 2000 , hotel sales in the area were $\$ 22.7$ million, supporting 595 jobs in the hotels and lodging sector (Minnesota IMPLAN Group 2000).

Table 2. Economic activity in the Rough River Lake Region, 2000

\begin{tabular}{|c|c|c|c|c|c|}
\hline Industry & $\begin{array}{l}\text { Output } \\
\text { (\$ millions) }\end{array}$ & Employment & $\begin{array}{l}\text { Employee Compensation } \\
\text { (\$ millions) }\end{array}$ & $\begin{array}{l}\text { Value Added } \\
\text { (\$ millions) }\end{array}$ & $\begin{array}{l}\% \\
\text { Output }\end{array}$ \\
\hline $\begin{array}{l}\text { Agriculture, Forestry, } \\
\text { Fish }\end{array}$ & 266.39 & $9,361.64$ & 21.51 & 159.16 & $2.8 \%$ \\
\hline Mining & 30.26 & 231.40 & 6.62 & 14.59 & $0.3 \%$ \\
\hline Construction & 686.12 & $6,792.04$ & 150.04 & 228.47 & $7.3 \%$ \\
\hline Food Processing & 294.04 & $1,297.23$ & 35.84 & 53.98 & $3.1 \%$ \\
\hline Apparel & 86.76 & 815.03 & 17.63 & 22.27 & $0.9 \%$ \\
\hline Manufacturing & $2,675.04$ & $12,701.23$ & 560.95 & 825.65 & $28.6 \%$ \\
\hline Sporting Goods & 7.37 & 64.46 & 1.60 & 2.94 & $0.1 \%$ \\
\hline Auto Parts and Access & 469.64 & $1,975.42$ & 100.94 & 136.21 & $5.0 \%$ \\
\hline $\begin{array}{l}\text { Transportation \& } \\
\text { Communication }\end{array}$ & 323.39 & $2,685.69$ & 74.19 & 144.53 & $3.5 \%$ \\
\hline Other Services & 970.61 & $15,904.64$ & 362.82 & 571.56 & $10.4 \%$ \\
\hline Wholesale Trade & 188.89 & $2,431.10$ & 73.37 & 128.64 & $2.0 \%$ \\
\hline Retail & 398.83 & $10,726.44$ & 178.59 & 320.56 & $4.3 \%$ \\
\hline Eating \& Drinking & 139.17 & $4,254.58$ & 46.46 & 69.26 & $1.5 \%$ \\
\hline $\begin{array}{l}\text { Finance, Insurance \& } \\
\text { Real Estate }\end{array}$ & 801.46 & $3,947.94$ & 68.79 & 570.90 & $8.6 \%$ \\
\hline $\begin{array}{l}\text { Hotels and Lodging } \\
\text { Places }\end{array}$ & 22.69 & 595.48 & 6.84 & 12.62 & $0.2 \%$ \\
\hline Auto Services & 65.32 & $1,005.49$ & 15.00 & 36.54 & $0.7 \%$ \\
\hline Other Amusements & 15.34 & 316.20 & 3.16 & 5.26 & $0.2 \%$ \\
\hline $\begin{array}{l}\text { Amusement and Rec } \\
\text { Services }\end{array}$ & 5.56 & 273.61 & 1.65 & 3.31 & $0.1 \%$ \\
\hline Gov't and Other & $1,915.69$ & $31,089.06$ & $1,282.18$ & $1,811.80$ & $20.5 \%$ \\
\hline Total & $9,362.57$ & $106,468.68$ & $3,008.17$ & $5,118.24$ & $100.0 \%$ \\
\hline
\end{tabular}

\footnotetext{
1 Independent Travel Industry Association and Kentucky Tourism Development Cabinet estimate of the economic impact of domestic travelers in the same region in 2002 was $\$ 227$ million and 4,273 jobs, “2002 Economic Impact Figures, (Word Document)," Kentucky Commerce Cabinet News, http://tourism.ky.gov/news.asp. (Accessed April 24, 2006).
} 


\section{Community Dock Owner Survey, 1998-99}

The Ecological Resources Branch (ERB) of the US Army Engineer Research and Development Center (ERDC) surveyed community dock owners at Table Rock Lake (Missouri/ Arkansas), Rough River Lake (Kentucky), and Pomme de Terre Lake (Missouri). The ERB staff designed the survey, constructed the instrument, and provided the frame (a list of community dock owners) to the Institution for Public Policy and Social Research (IPPSR) at Michigan State University (MSU) for sampling. IPPSR obtained additional approval through MSU's Human Subjects Office. The Office of Management and Budget authorized this study (Institute for Water Resources (IWR) 2006).

Working with the project managers, the ERB obtained lists of community dock owners. Once the contact information was received, MSU IPPSR staff sent a pre-contact mailer to the dock owners in the sample. This information packet included a description of the study and a FAQ sheet for the dock owner. In addition, the dock owners received a worksheet outlining the spending categories and other information regarding the upcoming telephone interview. Calls were made to dock owners in the randomly ordered sequence until a quota of interviews was completed. In this manner, 396 randomly selected community dock owners were interviewed at Rough River Lake.

Spending and trip information were obtained through a Computer Assisted Telephone Interview (CATI) survey conducted by MSU IPPSR staff. Dock owners were asked to document the number of boating trips on the lake that originated from their dock and to report trip spending associated with their most recent trip. Spending information was collected only for the most recent trip to reduce recall bias and avoid selective recall in which dock owners may report spending on the most expensive trips. The telephone interview lasted an average of 15 minutes. Other information needed to estimate parameters for this population was also acquired during the interview. 


\section{Results}

Results are provided in four parts: respondent profiles (including socioeconomic characteristics); recreation trip characteristics (amount of boat use, recreation activities and boat type); per-trip and annual spending; and the economic impacts of community dock owners'/ users' spending on the local region surrounding Rough River Lake.

\section{Respondent profiles}

The general characteristics of community dock owners as individuals and by households at Rough River Lake are shown in Figures 2 to 11. In general, the community dock owners were mostly white males with high education and income. Among the respondents, 83 percent were male and 78 percent were aged 46 and above (Figures 2 and 3). The average age was 56 (range $=24$ to 88 years old). The most frequent age (mode) was 67 . Fifty-one percent of the dock owners had at least some college education and 29 percent had college degrees or more. Nine percent of Rough River's community dock owners held graduate degrees (Figure 4). Almost all of the owners interviewed were white (Figure 5). All community dock slips have registered boats; surveys may or may not have been conducted with the registered boat owner. Ninety-four percent of the respondents were also the registered boat owner at the time of the interview (Figure 6).

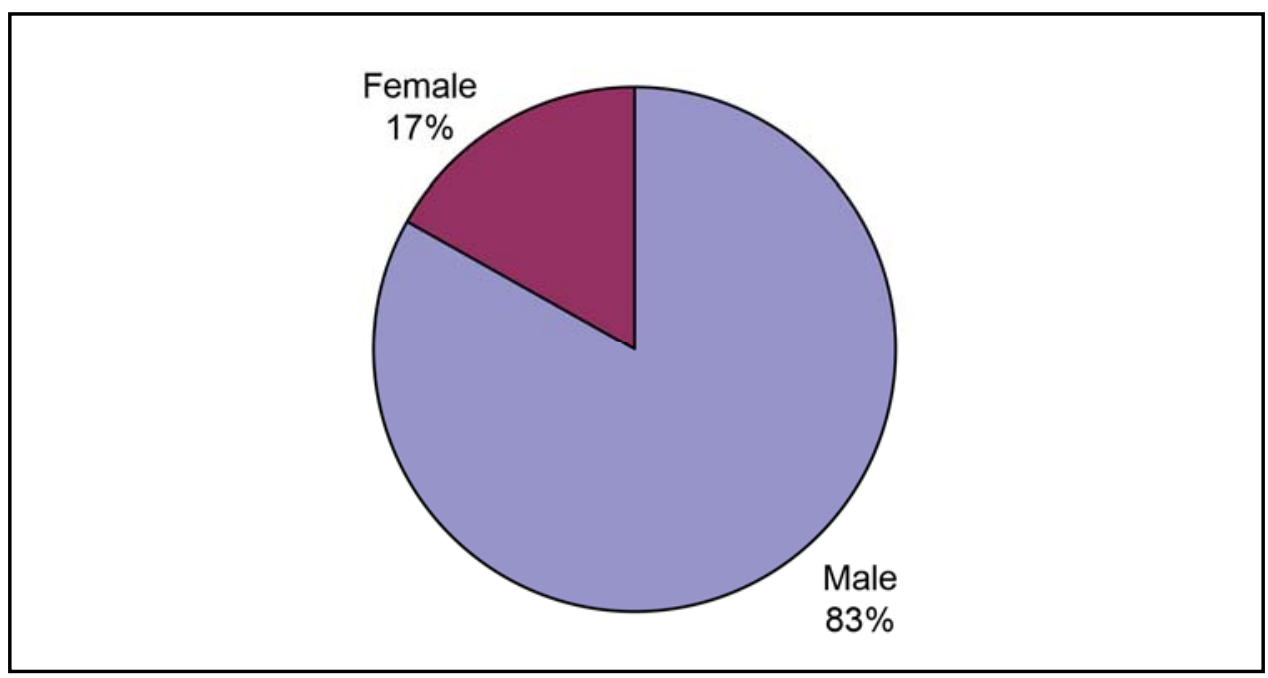

Figure 2. Gender of community dock owners at Rough River Lake, 1999 ( $N=396)$. 


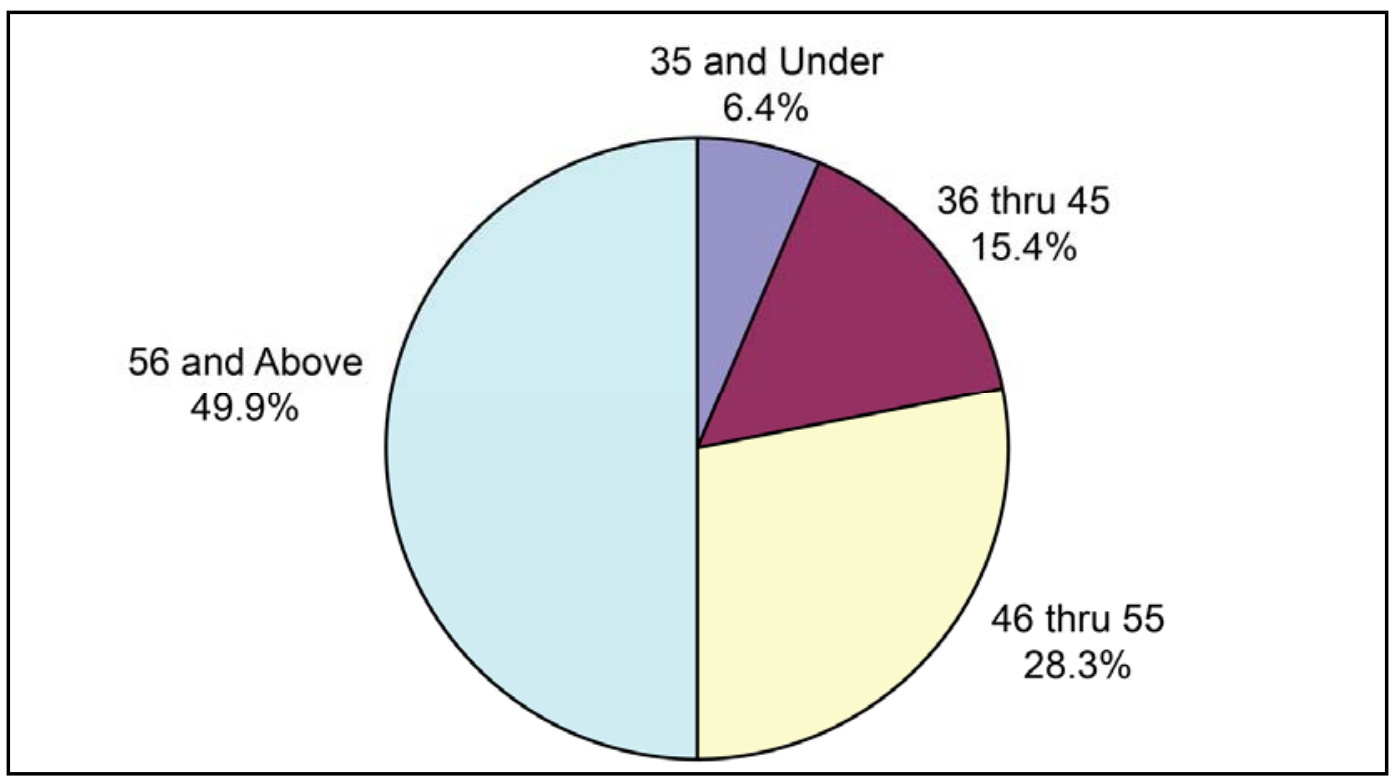

Figure 3. Age of community dock owners at Rough River lake, 1999 ( $\mathrm{N}=389)$.

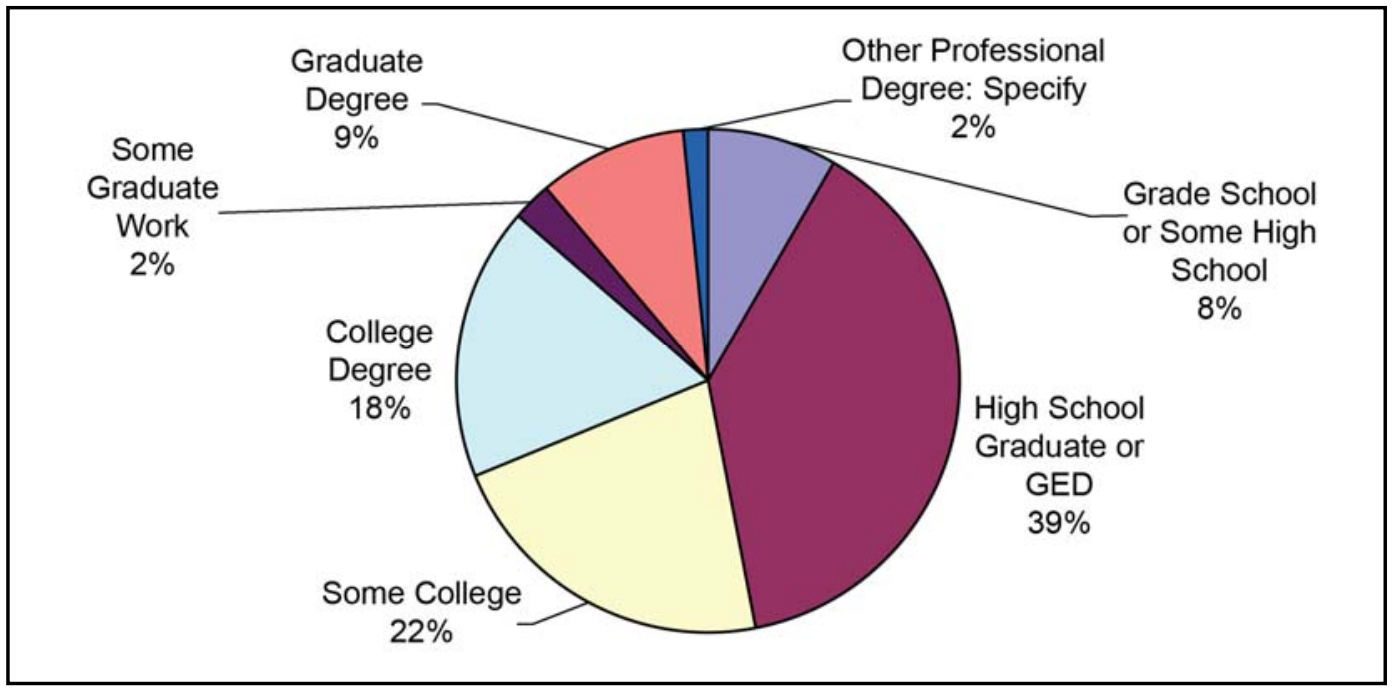

Figure 4. Education of community dock owners at Rough River Lake, 1999 ( $N=392)$. 


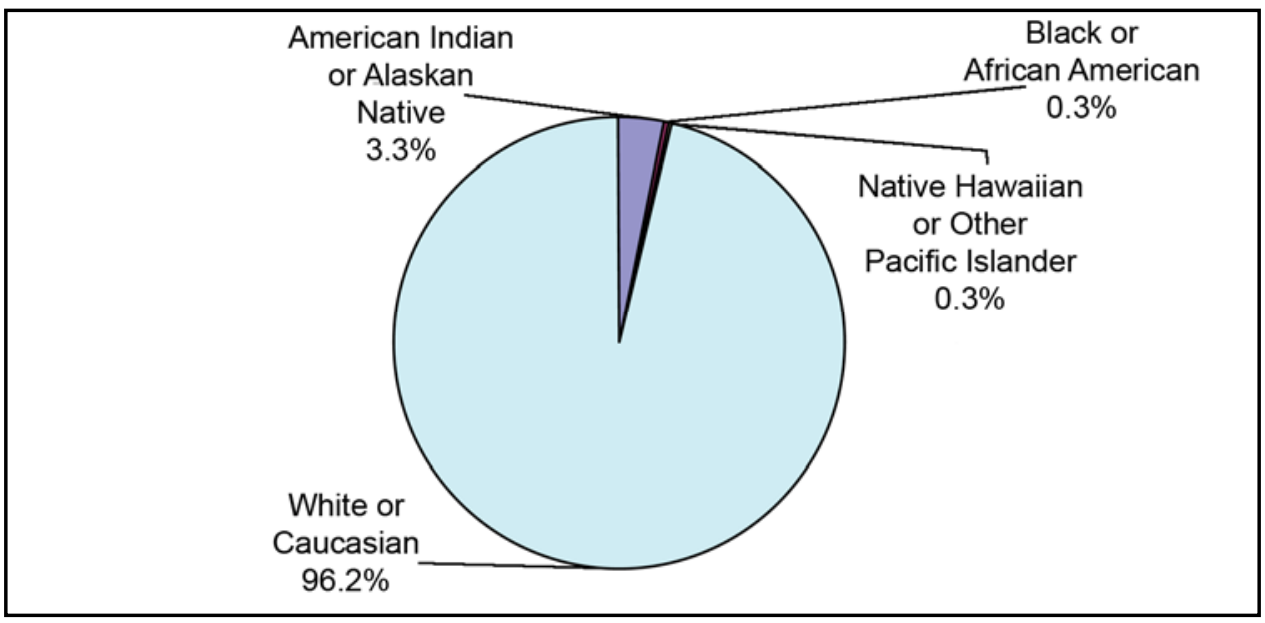

Figure 5. Race of community dock owners at Rough River Lake, 1999 (N=394) (about 1 percent were Hispanic or of Latino origin).

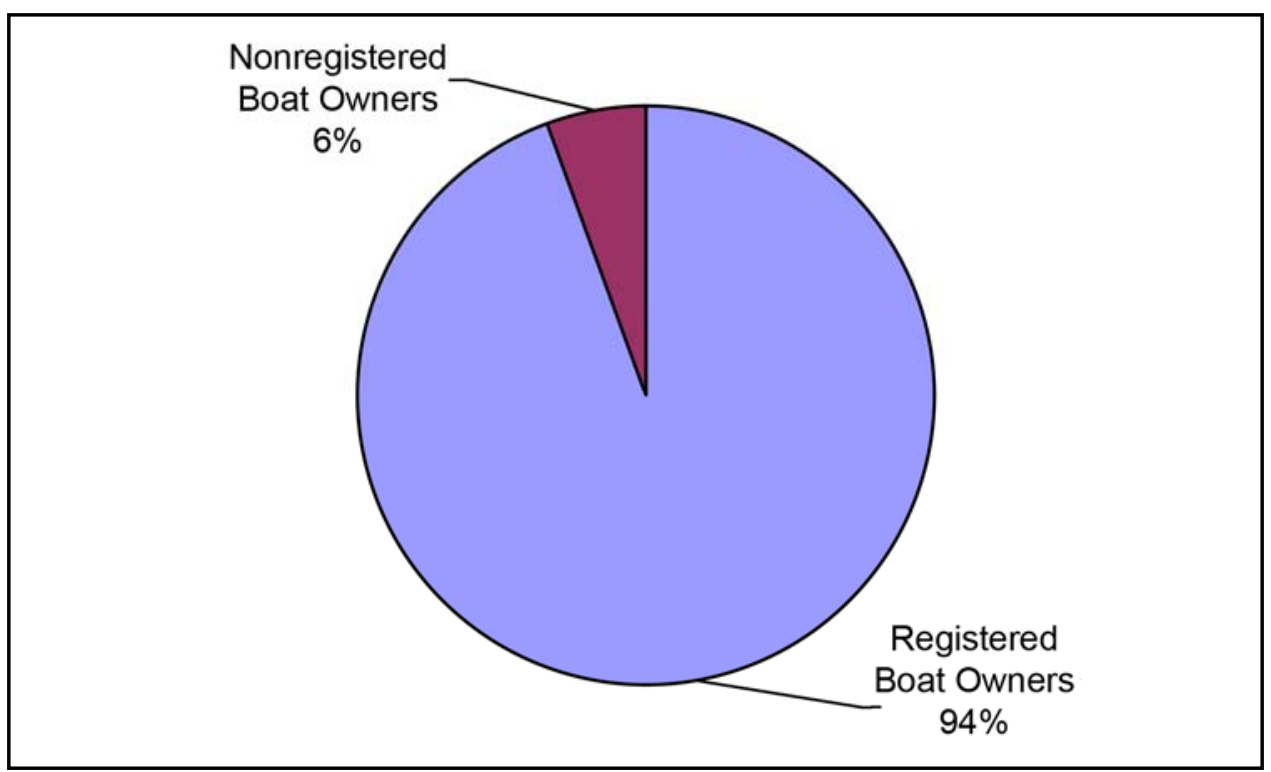

Figure 6. Surveys conducted with registered boat owners at Rough River Lake community docks, $1999(\mathrm{~N}=395)$.

Many owners of community docks reported high household incomes with no or few children living in the household. Forty-three percent of the respondents had annual household incomes of at least $\$ 60,000$, with 27 percent reporting incomes over $\$ 80,000$ (Figure 7). More than half of the dock owners lived in a household with two or less people and 68 percent of the respondents did not have any children under age 18 in their households (Figures 8 and 9). The average number of individuals per household was 3. The most frequent household size (mode) was 2. 


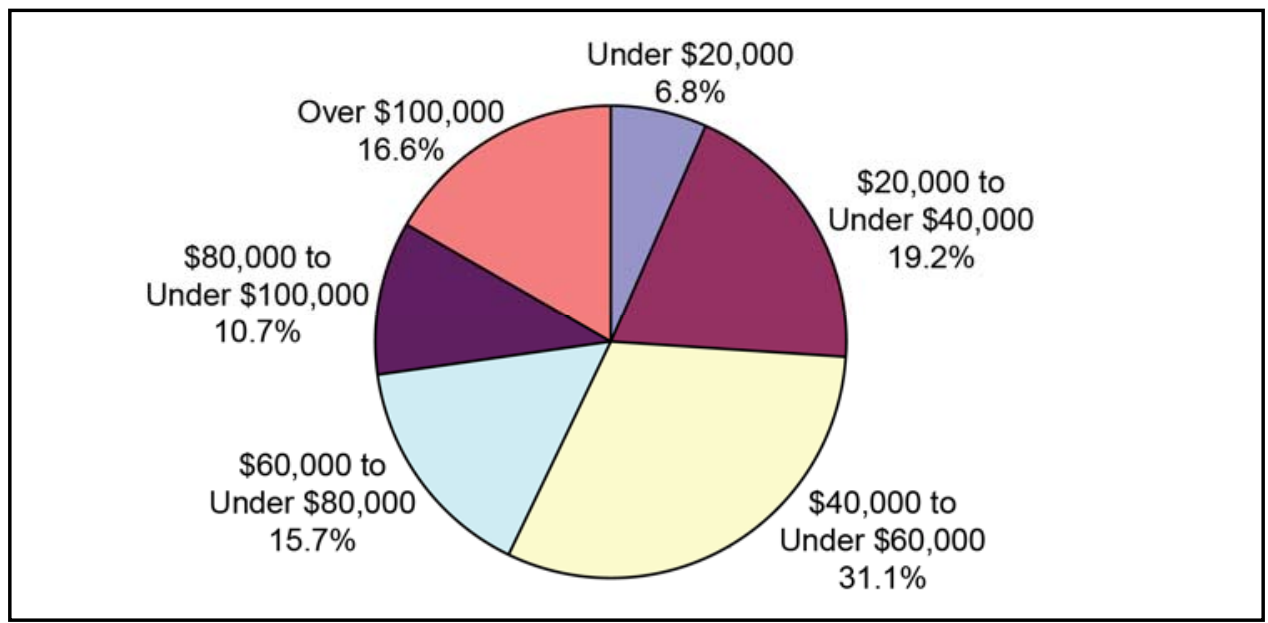

Figure 7. Household income of community dock owners at Rough River Lake, 1999 ( $N=338$ ).

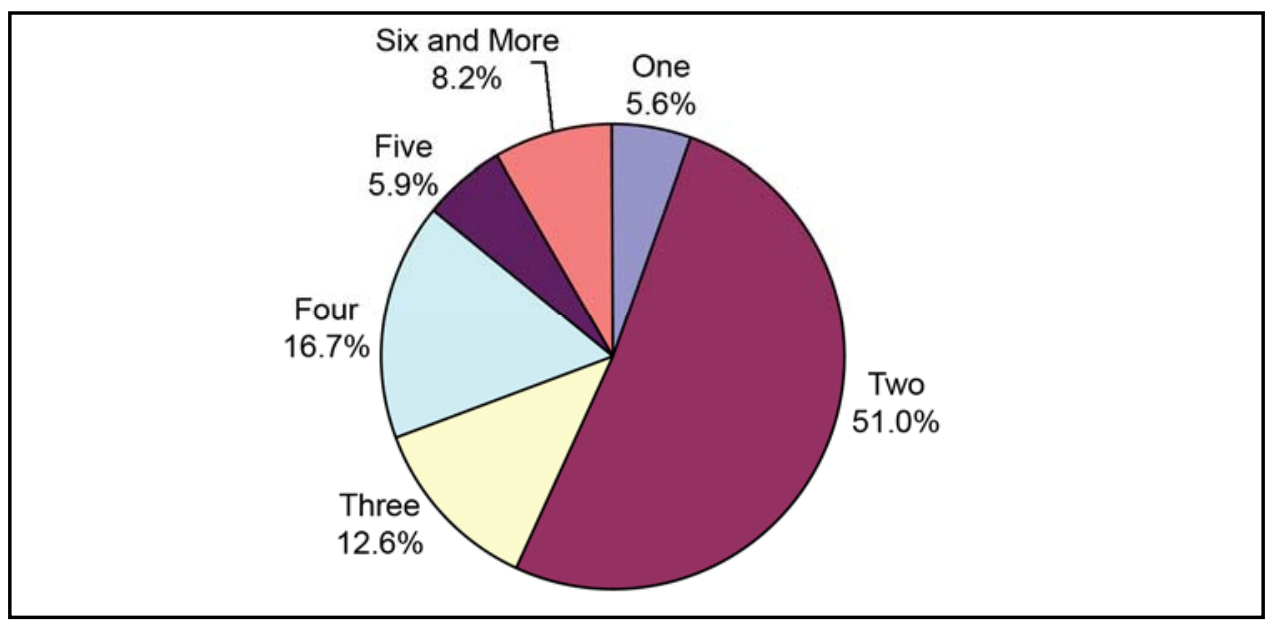

Figure 8. Household size of community dock owners at Rough River Lake, 1999 ( $N=390)$.

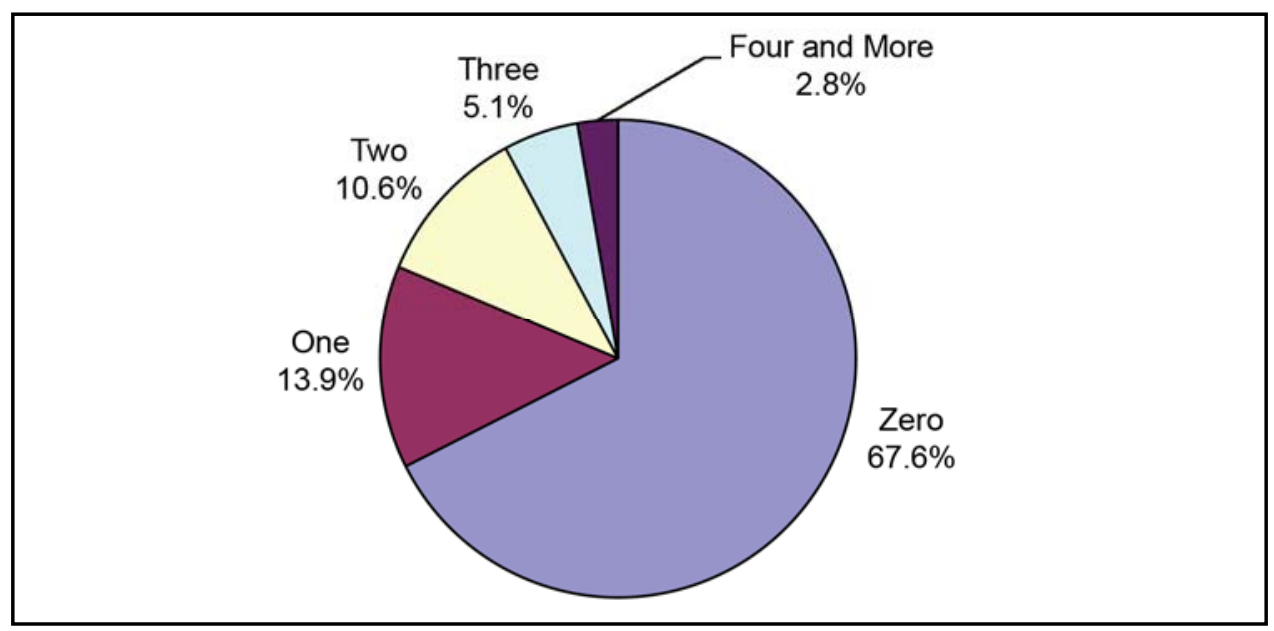

Figure 9. Number of people under 18 in households of community dock owners at Rough River Lake, 1999 ( $\mathrm{N}=395)$. 
The permanent residences of 44 percent of the community dock owners were within 30 miles of the community dock (Figure 10). The average distance from the dock owner's permanent home to the community dock was 43 miles. Eighty-three percent of the community dock owners owned a seasonal home within 30 miles of the dock (Figure 11).

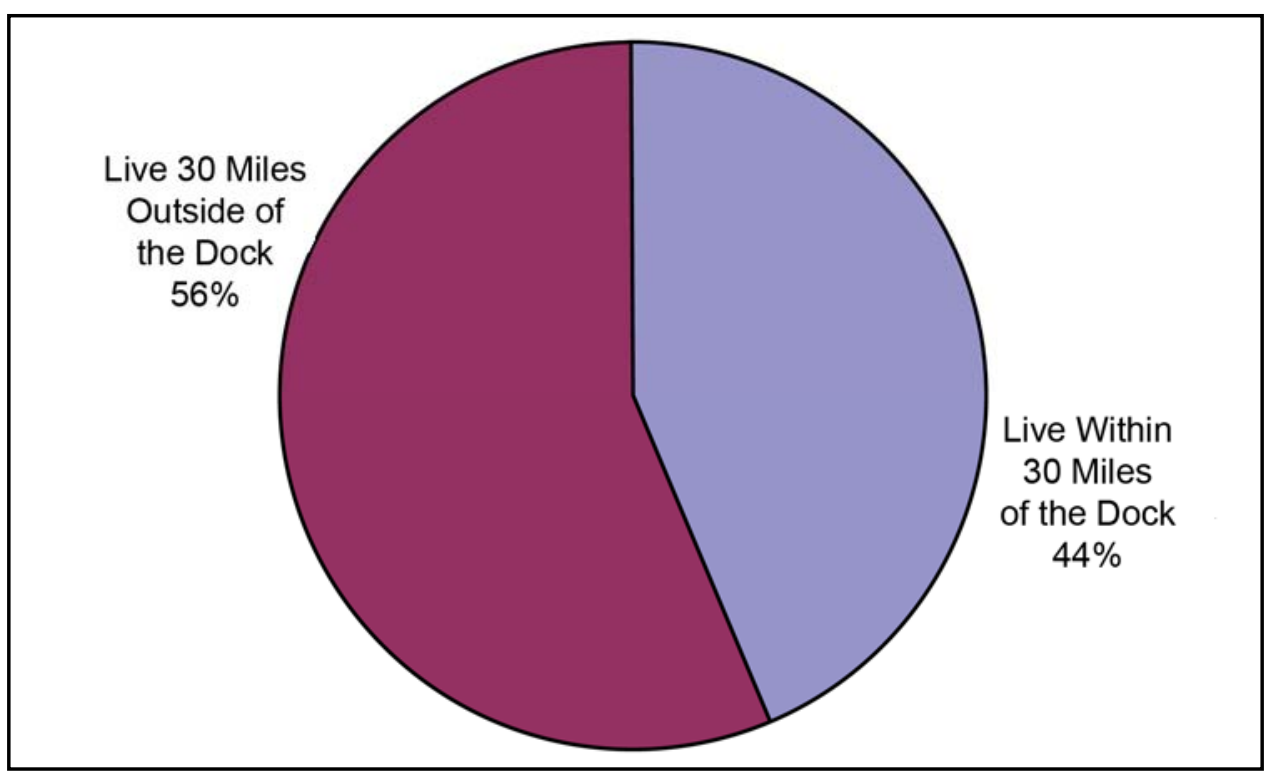

Figure 10. Permanent residence of community dock owners at Rough River Lake, 1999 $(\mathrm{N}=396)$.

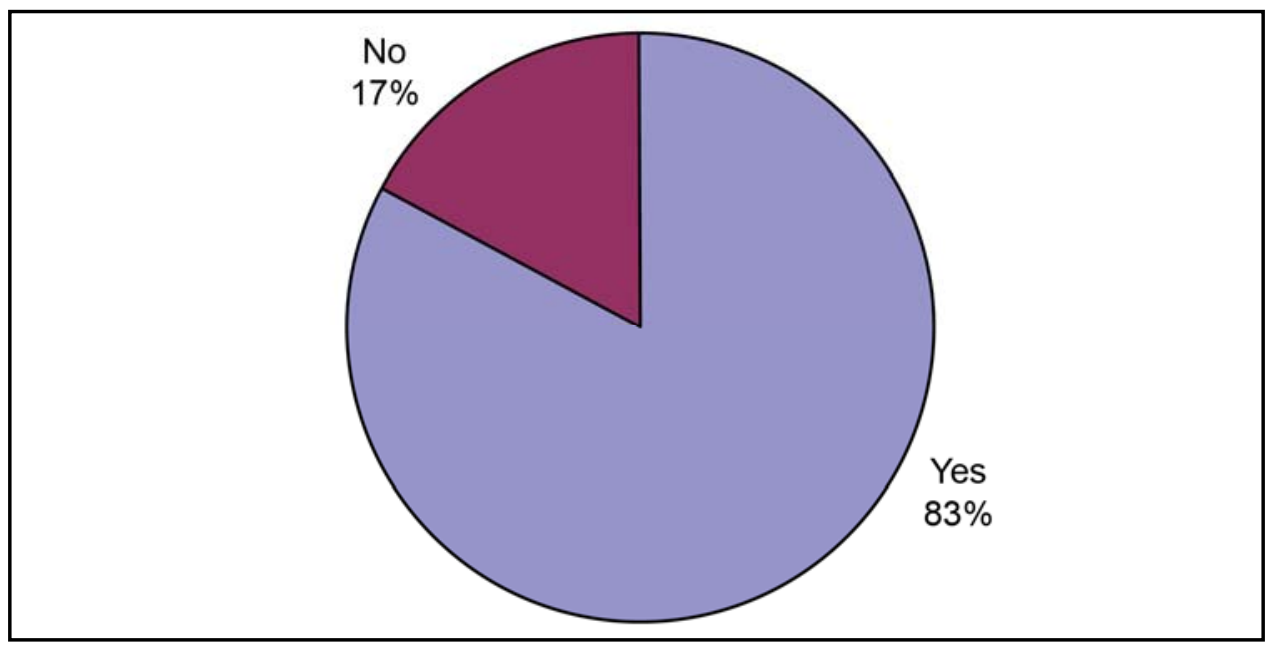

Figure 11. Seasonal home ownership of community dock owners at Rough River Lake, 1999 $(\mathrm{N}=396)$.

\section{Boating characteristics}

Respondents had been boating on Rough River Lake for an average of 18 years (range $=56$ years). On average, they and their guests 
(owners/ users) took 37.5 boating trips the previous year from September 1, 1998 to August 31, 19991. Half of them made 25 or fewer trips and 25 percent made 40 or more trips in the same period (Table 3 ). The majority of trips were taken in the summer (16 trips), followed by spring (9 trips). On average, the fewest number of trips were made in the winter (about 3 trips per dock owner). When asked to compare the number of boating trips made last year to the previous three years, 69 percent of the dock owners felt that they had made about the same number of boating trips. Thirteen percent said they had taken more trips last year than in the previous three years, and 18 percent said they had taken fewer trips (Figure 12).

Table 3. Number of trips to Rough River Lake community boat docks the previous year (09/01/1998 to 08/31/1999).

\begin{tabular}{|c|c|c|c|c|c|c|c|c|}
\hline \multirow[b]{2}{*}{ Trips } & \multirow[b]{2}{*}{ Average } & \multirow{2}{*}{$\begin{array}{l}\text { Std. } \\
\text { Error }\end{array}$} & \multirow[b]{2}{*}{ Minimum } & \multirow[b]{2}{*}{ Maximum } & \multicolumn{3}{|c|}{ Percentiles } & \multirow[b]{2}{*}{$N$} \\
\hline & & & & & 25 percent & 50 percent & 75 percent & \\
\hline Total number of trips & 37.52 & 2.40 & 0 & 365 & 15 & 25 & 40 & 370 \\
\hline Trips made in fall & 8.07 & 0.77 & 0 & 180 & 3 & 5 & 10 & 359 \\
\hline Trips made in winter & 2.75 & 0.35 & 0 & 90 & 0 & 0 & 3 & 360 \\
\hline Trips made in spring & 8.95 & 0.74 & 0 & 147 & 3 & 6 & 10.5 & 357 \\
\hline Trips made in summer & 16.30 & 1.22 & 0 & 180 & 6 & 12 & 15 & 359 \\
\hline
\end{tabular}

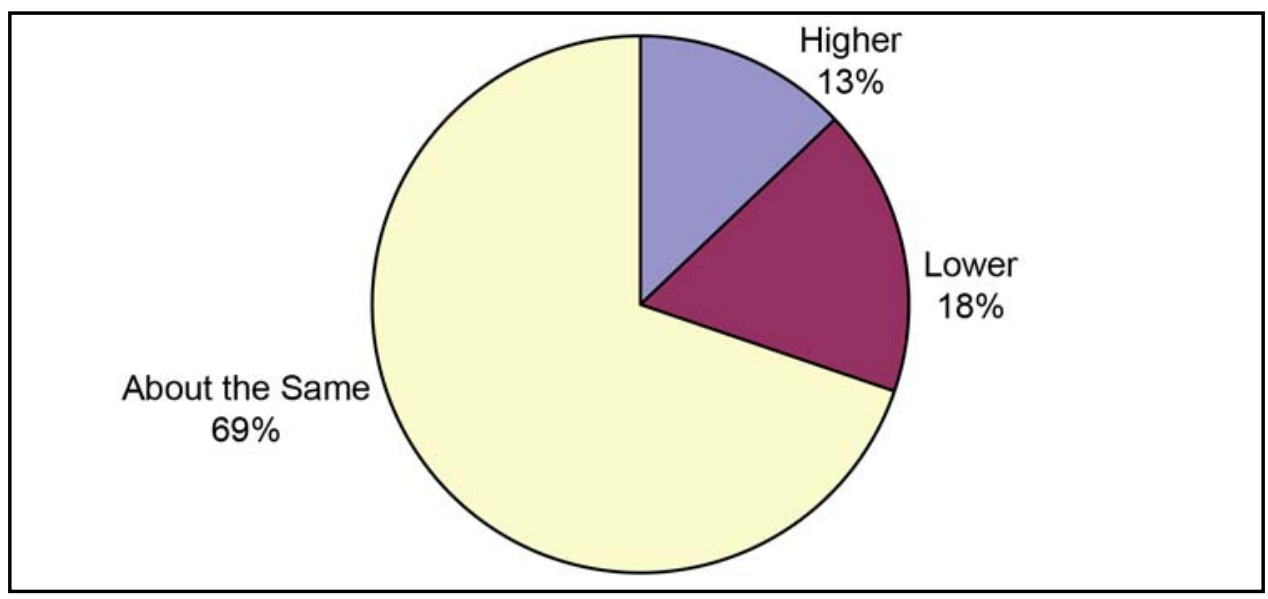

Figure 12. Number of boating trips made by community dock owners last year compared to previous three-year average at Rough River Lake, 1999 ( $\mathrm{N}=371)$.

\footnotetext{
1 Forty-four percent of the sampled dock owners had permanent residences within 30 miles of the community dock. Therefore, a large proportion of trips are local in origin.
} 


\section{Activities while boating}

During their boating trips the previous year, community dock owners/ users went swimming during 76.8 percent of their trips for an average of 29 times across the year (Table 4). Other activities they participated in included fishing from boats (on 47.8 percent of their boating trips), picnicking (35.6 percent), and water skiing (25.1 percent). The participation rates for scuba diving and hunting were both less than 2 percent of the total boating trips. Thirty-six percent of the owners/ users of community docks reported participating in other activities that were not mentioned during the telephone interviews (Figure 13). On average, dock owners/ users participated in other activities seven times during 19.5 percent of their boating trips the previous year (Table 4 ). The most frequent other activities were tubing or wave running ( 8 percent of respondents), cruising the lake for pleasure and other nonwater activities (4 percent), and sightseeing, golf, and socializing (3 percent each) (Figure 13).

Table 4. Recreation activity participation during previous year's trips to Rough River Lake community boat docks (09/01/1998 to 08/31/1999).

\begin{tabular}{|c|c|c|c|c|c|c|}
\hline Activity & Mean $^{1}$ & Percent of total trips ${ }^{2}$ & Std. Error of mean & Minimum & Maximum & $\mathrm{N}$ \\
\hline Boating & 32.93 & $87.74 \%$ & 2.75 & 0 & 365 & 360 \\
\hline Swimming & 28.82 & $76.79 \%$ & 2.75 & 0 & 365 & 364 \\
\hline Picnicking & 13.36 & $35.59 \%$ & 2.12 & 0 & 365 & 369 \\
\hline Fishing from boat & 17.92 & $47.76 \%$ & 2.17 & 0 & 365 & 365 \\
\hline Water skiing & 9.41 & $25.08 \%$ & 1.29 & 0 & 300 & 369 \\
\hline Camping & 3.75 & $10.00 \%$ & 0.64 & 0 & 130 & 370 \\
\hline Hiking & 5.44 & $14.50 \%$ & 0.80 & 0 & 200 & 366 \\
\hline Fishing from shore & 10.19 & $27.16 \%$ & 1.67 & 0 & 365 & 367 \\
\hline Scuba diving & 0.17 & $0.44 \%$ & 0.11 & 0 & 40 & 369 \\
\hline Hunting & 0.42 & $1.13 \%$ & 0.11 & 0 & 30 & 369 \\
\hline Other activities & 7.30 & $19.46 \%$ & 1.32 & 0 & 365 & 366 \\
\hline
\end{tabular}




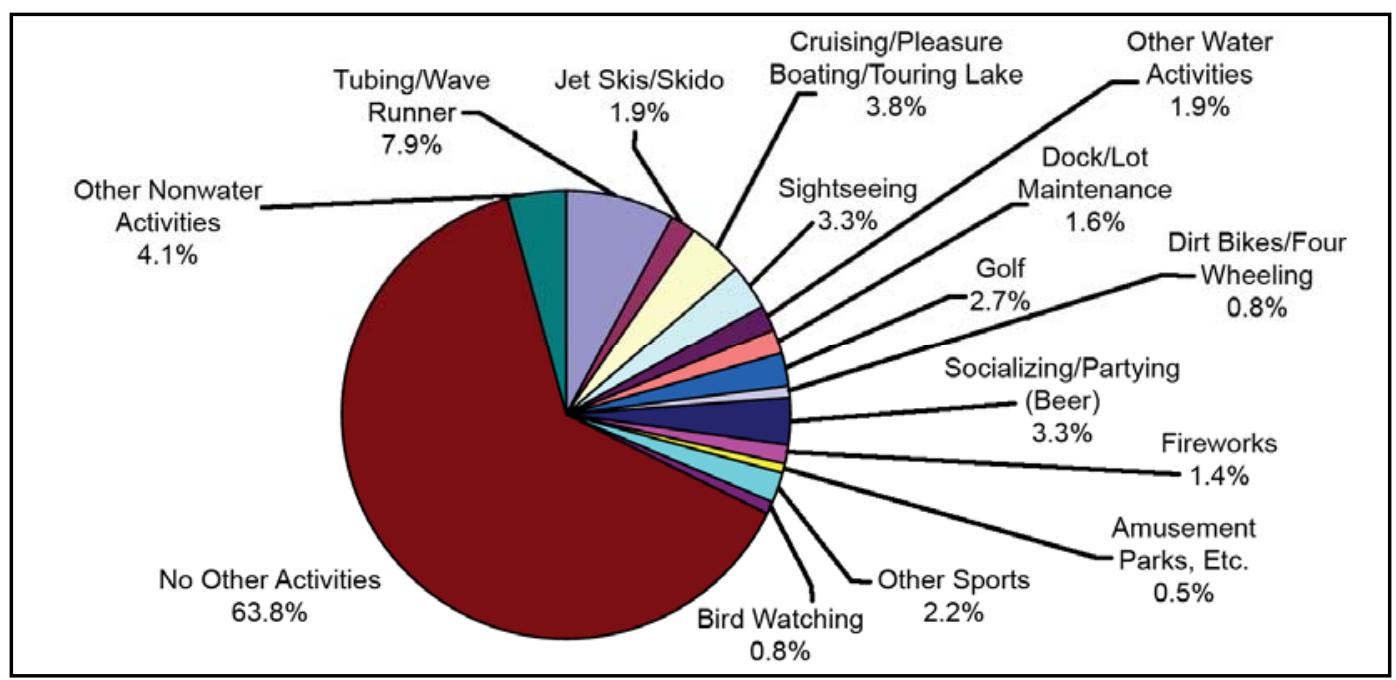

Figure 13. "What other activities did you or others participate in during your boating trips last year that I have not already mentioned?" (from Rough River Lake Community Docks, 1999, $\mathrm{N}=367$ ).

\section{Type of boat and motor}

Fifty-five percent of the boats surveyed at Rough River Lake communityowned docks were $20 \mathrm{ft}$ and under, with a minimum of $7 \mathrm{ft}$ (Table 5).

Forty-four percent were 21 to $30 \mathrm{ft}$ long, and less than 1 percent were $31 \mathrm{ft}$ and larger, with a maximum of $36 \mathrm{ft}$. Pontoon boats tended to be between 21 and $30 \mathrm{ft}$ while open boats were mostly shorter than $20 \mathrm{ft}$.

Table 5. Boat type and length cross-tabulation, Rough River Lake community dock owner survey, $1999(\mathrm{~N}=372)$.

\begin{tabular}{|l|r|r|r|r|r|r||}
\hline \multirow{2}{*}{ Boat Length } & \multicolumn{5}{|c|}{ Boat Type } & \multirow{2}{*}{} \\
\cline { 2 - 7 } & \multicolumn{1}{|c|}{ Open } & \multicolumn{1}{c|}{ Cabin } & \multicolumn{1}{l|}{ Pontoon } & \multicolumn{1}{l|}{ House } & \multicolumn{1}{l|}{ PWC } & \multicolumn{1}{|c|}{ Total } \\
\hline \hline $20^{\prime}$ and smaller & $37.90 \%$ & $0.00 \%$ & $15.86 \%$ & $0.00 \%$ & $1.34 \%$ & $55.11 \%$ \\
\hline $21^{\prime}$ to 30' & $7.26 \%$ & $1.61 \%$ & $35.48 \%$ & $0.00 \%$ & $0.00 \%$ & $44.35 \%$ \\
\hline $31^{\prime}$ and larger & $0.00 \%$ & $0.00 \%$ & $0.27 \%$ & $0.27 \%$ & $0.00 \%$ & $0.54 \%$ \\
\hline Total & $45.16 \%$ & $1.61 \%$ & $51.61 \%$ & $0.27 \%$ & $1.34 \%$ & $100.00 \%$ \\
\hline
\end{tabular}

Seventy-five percent of the boats used at the community-owned docks did not include inboard motors. The majority of cabin boats had inboard motors, while most pontoons and open boats did not (Table 6). In general, the larger the boat, the lower the percentage of inboard motors (Table 7). 
Table 6. Boat type and motor cross-tabulation, Rough River Lake community dock owner survey, $1999(\mathrm{~N}=366)$.

\begin{tabular}{|c|c|c|c|c|c|}
\hline \multirow[b]{2}{*}{ Inboard Motor } & \multicolumn{4}{|c|}{ Boat Type } & \multirow[b]{2}{*}{ Total } \\
\hline & Open & Cabin & Pontoon & PWC & \\
\hline With & $19.95 \%$ & $1.64 \%$ & $1.64 \%$ & $1.64 \%$ & $24.86 \%$ \\
\hline Without & $24.32 \%$ & $0.27 \%$ & $50.00 \%$ & $0.55 \%$ & $75.14 \%$ \\
\hline Total & $44.27 \%$ & $1.91 \%$ & $51.64 \%$ & $2.19 \%$ & $100.00 \%$ \\
\hline
\end{tabular}

Table 7. Boat length and motor cross-tabulation, Rough River Lake community dock owner survey, $1999(\mathrm{~N}=355)$.

\begin{tabular}{|c|c|c|c|c|}
\hline \multirow[b]{2}{*}{ Inboard Motor } & \multicolumn{3}{|c|}{ Boat Length } & \\
\hline & 20 and Smaller & $21^{\prime}$ to $30^{\prime}$ & 31' and Larger & \\
\hline With & $16.06 \%$ & $8.73 \%$ & $0.00 \%$ & $24.79 \%$ \\
\hline Without & $38.31 \%$ & $36.62 \%$ & $0.28 \%$ & $75.21 \%$ \\
\hline Total & $54.37 \%$ & $45.35 \%$ & $0.28 \%$ & $100.00 \%$ \\
\hline
\end{tabular}

\section{Dock user segments and spending}

Spending averages were estimated for all of Rough River Lake's community-owned dock users (Table 8) and for two different segments based on length of stay (Table 9) and boat length (Table 10). Dividing visitors into segments helps explain differences in spending across distinct user groups. It gives managers the opportunity to apply these distinct spending profiles to project level use data. The two types of segments that fulfilled these purposes were: day user versus overnight stay segments and segments based on length of the boat.

\section{Average spending for full sample of community dock owners}

Users of community-owned docks averaged \$192 in trip expenses associated with their last boating trip (for a party of 4.9 people). Dock users stayed away from home an average of 2.4 nights and used their boat 2.4 days during their last trip (Table 8). Seventy-nine percent (\$151) of spending occurred within 30 miles of their boat dock. Of the expenditures made within 30 miles of the community dock, users spent the most on groceries ( $\$ 35$ per party trip), followed by gas and oil for their boat $(\$ 29)$, 
Table 8. Summary of Rough River Lake community dock owners'/users' spending and use profiles, 09/1998 to 08/1999 (spending per party trip).

\begin{tabular}{|c|c|c|c|c|c|c|c|c|}
\hline Spending Categories & Mean & $\begin{array}{l}\text { Std. } \\
\text { Error }\end{array}$ & $\begin{array}{l}\text { Pct. } \\
\text { Error }^{1}\end{array}$ & $N$ & Minimum & Maximum & $\begin{array}{l}\text { Pct. } \\
\text { zeroes }\end{array}$ & $\begin{array}{l}\text { Mean exc. } \\
\text { zero }\end{array}$ \\
\hline \multicolumn{9}{|c|}{ Spending Information for Last Trip } \\
\hline Gas/oil auto & $\$ 12.15$ & $\$ 1.03$ & $8 \%$ & 387 & $\$ 0$ & $\$ 220$ & $47 \%$ & $\$ 22.94$ \\
\hline Other expenses auto & $\$ 2.21$ & $\$ 1.07$ & $49 \%$ & 387 & $\$ 0$ & $\$ 400$ & $93 \%$ & $\$ 30.50$ \\
\hline Gas/oil boat & $\$ 28.59$ & $\$ 1.85$ & $6 \%$ & 386 & $\$ 0$ & $\$ 500$ & $8 \%$ & $\$ 31.09$ \\
\hline Other expenses boat & $\$ 20.36$ & $\$ 5.00$ & $25 \%$ & 387 & $\$ 0$ & $\$ 850$ & $81 \%$ & $\$ 106.49$ \\
\hline Food/drink restaurants & $\$ 20.44$ & $\$ 1.66$ & $8 \%$ & 385 & $\$ 0$ & $\$ 300$ & $46 \%$ & $\$ 38.20$ \\
\hline Groceries & $\$ 35.11$ & $\$ 2.52$ & $7 \%$ & 381 & $\$ 0$ & $\$ 400$ & $24 \%$ & $\$ 45.97$ \\
\hline Campground fees & $\$ 2.10$ & $\$ 0.98$ & $47 \%$ & 390 & $\$ 0$ & $\$ 300$ & $96 \%$ & $\$ 58.50$ \\
\hline Lodging & $\$ 0.35$ & $\$ 0.22$ & $63 \%$ & 390 & $\$ 0$ & $\$ 75$ & $99 \%$ & $\$ 33.75$ \\
\hline Recreation fees & $\$ 7.12$ & $\$ 1.22$ & $17 \%$ & 387 & $\$ 0$ & $\$ 250$ & $83 \%$ & $\$ 41.73$ \\
\hline Sporting goods & $\$ 8.57$ & $\$ 2.21$ & $26 \%$ & 388 & $\$ 0$ & $\$ 600$ & $84 \%$ & $\$ 54.49$ \\
\hline Other Supplies & $\$ 13.98$ & $\$ 3.03$ & $22 \%$ & 387 & $\$ 0$ & $\$ 890$ & $55 \%$ & $\$ 30.74$ \\
\hline Total within 30 miles & $\$ 150.97$ & & & & & & & \\
\hline Expenses for $30+$ miles $^{2}$ & $\$ 41.35$ & $\$ 3.91$ & $9 \%$ & 371 & $\$ 0$ & $\$ 900$ & $39 \%$ & \\
\hline Total trip spending & $\$ 192.33$ & & & & & & & \\
\hline $\begin{array}{l}\text { Pct. of local spending (within } \\
30 \text { miles) }\end{array}$ & $78.50 \%$ & & & & & & & \\
\hline \multicolumn{9}{|c|}{ Use Information for Last Trip } \\
\hline Nights away from home & 2.36 & 0.12 & $5 \%$ & 385 & 0 & 15 & & \\
\hline Days used boat & 2.38 & 0.09 & $4 \%$ & 366 & 1 & 15 & & \\
\hline Number of people on boat & 4.88 & 0.18 & $4 \%$ & 376 & 1 & 25 & & \\
\hline \multicolumn{9}{|c|}{ Annual Spending for Last Year (09/01/98 - 08/31/99) } \\
\hline Storage fees & $\$ 125.99$ & $\$ 9.31$ & $7 \%$ & 353 & $\$ 0$ & $\$ 1,200$ & & \\
\hline Insurance payments & $\$ 212.80$ & $\$ 8.49$ & $4 \%$ & 298 & $\$ 0$ & $\$ 1,000$ & & \\
\hline Boat repair/maintenance & $\$ 223.79$ & $\$ 32.42$ & $14 \%$ & 345 & $\$ 0$ & $\$ 8,500$ & & \\
\hline Dock maintenance/repair & $\$ 122.91$ & $\$ 19.54$ & $16 \%$ & 358 & $\$ 0$ & $\$ 3,000$ & & \\
\hline \multicolumn{9}{|c|}{ Use Information for Last Year (09/01/98 - 08/31/99) } \\
\hline Number of trips using boat & 37.54 & 2.41 & $6 \%$ & 369 & 0 & 365 & & \\
\hline $\begin{array}{l}\text { Cost of the boat (in } 1999 \\
\text { dollars) }\end{array}$ & $\$ 12,581.10$ & $\$ 593.56$ & $5 \%$ & 328 & $\$ 160.30$ & $\$ 150,000.00$ & & \\
\hline
\end{tabular}


restaurant meals ( $\$ 20)$, and other boat expenses ( $\$ 20)$. A refined average of 38 boating trips were made from each slip in a community-owned dock during the previous year.

A community dock is permitted under a shoreline use permit. The applicant is charged a $\$ 30.00$ fee for a five-year permit which includes a $\$ 10.00$ administration charge and \$5.00 annual inspection fee. Other storage fees that are identified in annual spending do not include the permit fee but relate to additional spending that may be paid by the end user, for example in off-site storage when the craft is not in the water.

Community dock owners spent an average of $\$ 126$ on storage fees, $\$ 213$ on insurance, $\$ 224$ on boat repair and maintenance, and $\$ 123$ on their share of dock repair and maintenance (Table 8). The average cost of the boat was $\$ 12,581$ (1999 dollars). The lowest boat cost was $\$ 160$ and the highest was $\$ 150,000$.

When asked to compare the amount spent on their most recent trip to prior similar trips, 70 percent of the dock owners felt that they had made about the same expenditures. Fifteen percent said they had spent more on the most recent trip than on similar trips in the past 12 months, and 15 percent said they had spent less (Figure 14).

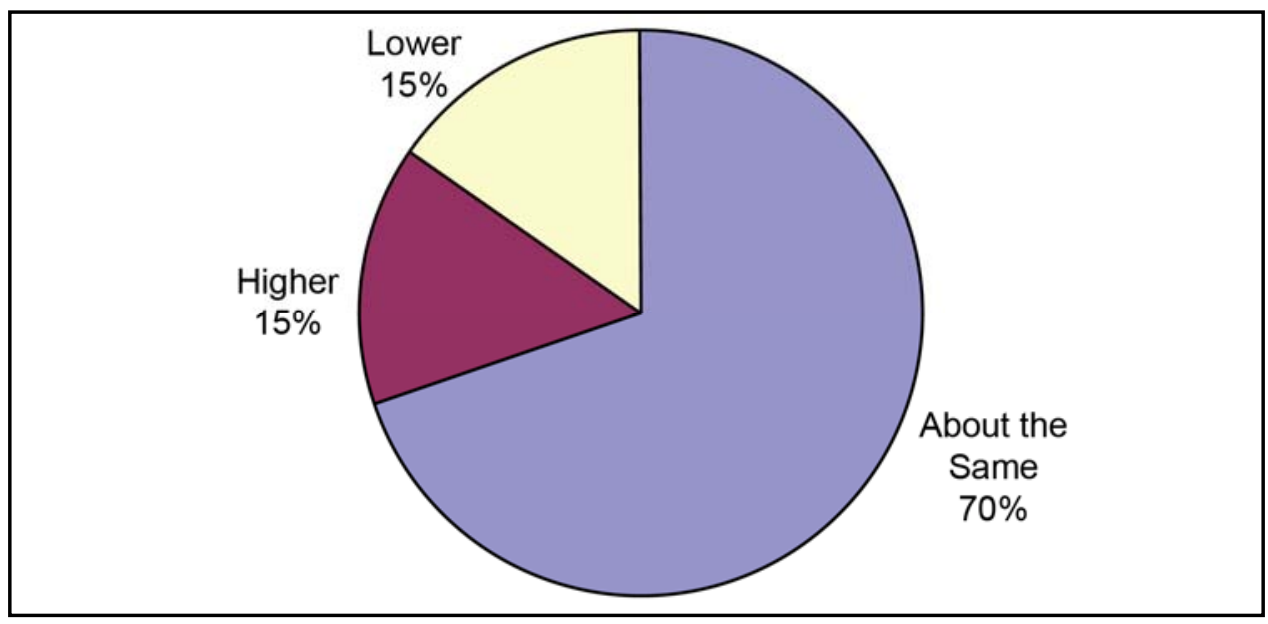

Figure 14. Expenditures by community dock owners/users on most recent trip compared to similar trips in the last 12 months at Rough River Lake, 1999 ( $N=385)$.

Many of the respondents reported no spending on their last trip in many of the spending categories listed. Categories in which a large percentage (more than 80 percent) of users did not spend money on their last trip 
were: lodging (99 percent), campground fees (96 percent), other expenses on auto (93 percent), sporting goods (84 percent), recreation fees (83 percent), and other expenses on boat (81 percent). Although the estimates of average trip expenditures in this report are based on the full sample, it is worthwhile to recognize the difference between the average spending of all community dock users and the average spending of just the spenders. The average spending of those who spent something on an item is generally much higher than the average computed from all visitors. For instance, while the average across all community dock users was $\$ 2.10$ on campground fees per party trip, the dock parties who did spend money on campground fees spent an average of $\$ 59$ per party trip (Table 8). For estimating total spending of all Rough River Lake community dock users, it is appropriate to apply the means that include zeros. The means without zeros should not be used to expand the data to population totals, as they represent spending for specific segments only (i.e., dock users who stayed at campgrounds spent an average of $\$ 59$ on campground fees per trip).

\section{Average spending by segment: Day use versus overnight}

Rough River community dock owners were grouped into two segments based on whether or not they stayed overnight away from their permanent home during their last trip. The dock owners/ users who did not stay away from home (i.e., day users) spent an average of $\$ 113$ for that trip, 85 percent of which (\$97) was spent within 30 miles of the boat dock (Table 9). The average party size was 4.5 people per trip. The dock owners/ users who stayed overnight spent an average of 3.2 nights away from home and used the boat for 2.9 days with a party size of 5 people per trip. They spent an average of $\$ 219$ for the entire trip, 77 percent of which (\$168) was spent within 30 miles of the boat dock. Day users made an average of 55 boating trips in the previous year, whereas overnighters made 32 trips.

Community dock owners in the overnight segment owned more expensive boats than day users ( $\$ 13,322$ vs. $\$ 10,797$, respectively). The overnight segment of dock owners also paid more annually for insurance, dock maintenance, and storage than day users. However, day users spent slightly more on boat repair.

Day users comprised 27 percent of the sample of community dock users, while 73 percent spent at least one night in the area on their last trip. In terms of total spending in the local region, day users of community docks contributed 26 percent and overnight stay dock users, 74 percent. 
Table 9. Spending and use by length of stay segments, Rough River Lake community dock owner survey, 09/1998 to 08/1999 (spending per party trip).

\begin{tabular}{|c|c|c|c|c|c|c|c|c|}
\hline \multirow[b]{2}{*}{ Spending Categories } & \multicolumn{4}{|c|}{ Day Users } & \multicolumn{4}{|c|}{ Overnight Users } \\
\hline & Mean & $\begin{array}{l}\text { Std. } \\
\text { Error }\end{array}$ & $\begin{array}{l}\text { Pct. } \\
\text { Error }{ }^{1}\end{array}$ & $\mathrm{~N}$ & Mean & $\begin{array}{l}\text { Std. } \\
\text { Error }\end{array}$ & $\begin{array}{l}\text { Pct. } \\
\text { Error }^{1}\end{array}$ & $\mathrm{~N}$ \\
\hline \multicolumn{9}{|c|}{ Per Party Trip Spending } \\
\hline Gas/oil auto & $\$ 3.18$ & $\$ 1.30$ & $41 \%$ & 100 & $\$ 15.20$ & $\$ 1.27$ & $8 \%$ & 280 \\
\hline Other expenses auto & $\$ 4.36$ & $\$ 3.96$ & $91 \%$ & 101 & $\$ 1.35$ & $\$ 0.37$ & $28 \%$ & 278 \\
\hline Gas/oil boat & $\$ 17.74$ & $\$ 1.94$ & $11 \%$ & 98 & $\$ 31.36$ & $\$ 1.73$ & $6 \%$ & 279 \\
\hline Other expenses boat & $\$ 18.94$ & $\$ 7.47$ & $39 \%$ & 99 & $\$ 18.95$ & $\$ 5.90$ & $31 \%$ & 280 \\
\hline Restaurants & $\$ 10.18$ & $\$ 2.58$ & $25 \%$ & 98 & $\$ 24.43$ & $\$ 2.06$ & $8 \%$ & 279 \\
\hline Groceries & $\$ 16.88$ & $\$ 3.81$ & $23 \%$ & 98 & $\$ 42.00$ & $\$ 3.09$ & $7 \%$ & 276 \\
\hline Campground fees & $\$ 0.00$ & - & - & 100 & $\$ 2.90$ & $\$ 1.36$ & $47 \%$ & 282 \\
\hline Lodging & $\$ 0.00$ & - & - & 100 & $\$ 0.48$ & $\$ 0.30$ & $63 \%$ & 282 \\
\hline Recreation fees & $\$ 2.97$ & $\$ 1.28$ & $43 \%$ & 98 & $\$ 8.73$ & $\$ 1.61$ & $18 \%$ & 282 \\
\hline Sporting goods & $\$ 7.31$ & $\$ 3.38$ & $46 \%$ & 99 & $\$ 9.25$ & $\$ 2.82$ & $30 \%$ & 281 \\
\hline Other supplies & $\$ 14.95$ & $\$ 5.29$ & $35 \%$ & 100 & $\$ 13.80$ & $\$ 3.74$ & $27 \%$ & 280 \\
\hline Total within 30 miles & $\$ 96.51$ & & & & $\$ 168.46$ & & & \\
\hline Expenses $30+$ Miles $^{2}$ & $\$ 16.97$ & $\$ 3.73$ & $22 \%$ & 93 & $\$ 50.47$ & $\$ 5.07$ & $10 \%$ & 272 \\
\hline Total trip spending & $\$ 113.48$ & & & & $\$ 218.94$ & & & \\
\hline $\begin{array}{l}\text { Pct. of local spending (within } 30 \\
\text { miles) }\end{array}$ & $85 \%$ & & & & $77 \%$ & & & \\
\hline \multicolumn{9}{|c|}{ Annual Spending } \\
\hline Storage fees & $\$ 111.54$ & $\$ 18.53$ & $17 \%$ & 92 & $\$ 133.52$ & $\$ 10.98$ & $8 \%$ & 254 \\
\hline Insurance payments & $\$ 175.08$ & $\$ 13.31$ & $8 \%$ & 77 & $\$ 227.92$ & $\$ 10.47$ & $5 \%$ & 217 \\
\hline Boat repair/maintenance & $\$ 232.85$ & $\$ 62.92$ & $27 \%$ & 89 & $\$ 223.78$ & $\$ 38.91$ & $17 \%$ & 249 \\
\hline Dock maintenance/repair & $\$ 65.30$ & $\$ 14.84$ & $23 \%$ & 89 & $\$ 134.68$ & $\$ 25.15$ & $19 \%$ & 261 \\
\hline Cost of the boat (in 1999 dollars) & $\$ 10,796.68$ & $\$ 825.86$ & $8 \%$ & 79 & $\$ 13,322.29$ & $\$ 747.89$ & $6 \%$ & 243 \\
\hline \multicolumn{9}{|c|}{ Visitor Characteristics } \\
\hline Total trips using boat (last year) & 55.19 & 6.92 & $13 \%$ & 94 & 31.81 & 2.13 & $7 \%$ & 269 \\
\hline Nights away from home (last trip) & 0.00 & - & - & 103 & 3.22 & 0.13 & $4 \%$ & 282 \\
\hline Days used boat (last trip) & 1.00 & - & - & 95 & 2.88 & 0.11 & $4 \%$ & 267 \\
\hline People on boat (last trip) & 4.46 & 0.31 & $7 \%$ & 98 & 5.01 & 0.21 & $4 \%$ & 271 \\
\hline
\end{tabular}




\section{Average spending by boat length segments}

Based on the length of the boat, community dock owners were grouped into three segments: boats that were $20 \mathrm{ft}$ and shorter, boats between 21 and $30 \mathrm{ft}$, and boats $31 \mathrm{ft}$ and longer. The 20 -ft and smaller segment spent an average of $\$ 206$ per party on the last trip during which about 77 percent (\$159) was spent within 30 miles of the boat dock (Table 10). They stayed an average of 2.2 nights away from home and used their boat for 2.3 days with a party size of 4.5 people per trip. Dock owners/ users in this segment made an average of 40 boating trips the previous year.

The 21- to 30-ft boat segment spent an average of $\$ 185$ per party on the last trip (\$151 within 30 miles of the boat dock). They stayed an average of 2.6 nights away from home, used their boat for 2.6 days, with a party size of 5.4 people per trip. They made an average of 36 boating trips the previous year.

Community dock owners/ users in the largest boat size segment averaged $\$ 203$ per party on goods and services during their last trip ( $\$ 88$ of the money was spent locally). They stayed away from home an average of one night and used the boat for two days per trip. The average party size for this group was three people per trip. Dock users in this segment made an average of 76 boating trips the previous year. Due to the low number (2) of respondents for this boat length category, these results may not be reliable.

In general, the larger the boat, the higher the annual expenses for community dock owners. ${ }^{1}$ Storage fees ranged from $\$ 110$ for boats $20 \mathrm{ft}$ and shorter to $\$ 149$ for boats 21 to $30 \mathrm{ft}$ in length. The cost of the boat ranged from $\$ 11,126$ for the 20-ft and shorter segment to $\$ 14,552$ for the 21- to 30 -ft segment, while the insurance payments ranged from $\$ 200$ to $\$ 225$. Boat repair and maintenance costs similarly grew from $\$ 186$ to $\$ 279$ per year as boat size increased (Table 10).

Nearly 55 percent of the sample had small-sized boats ( $20 \mathrm{ft}$ and smaller), while 44 percent were medium ( 21 to $30 \mathrm{ft}$ ) and less than 1 percent were large (above $31 \mathrm{ft}$ ). Dock users with small length boats contributed 59 percent of total spending locally, and those with medium-size boats contributed 41 percent.

1 Due to the low number of responses, the 31-ft and longer category was excluded from these findings. 
Table 10. Spending and use by boat length segments, Rough River Lake community dock owner survey, 09/1998 to 08/1999 (spending per party trip).

\begin{tabular}{|c|c|c|c|c|c|c|c|c|c|c|c|c|}
\hline \multirow[b]{2}{*}{ Spending Categories } & \multicolumn{4}{|c|}{$20^{\prime}$ and Smaller } & \multicolumn{4}{|c|}{$21^{\prime}$ to $30^{\prime}$} & \multicolumn{4}{|c|}{ 31' and Larger } \\
\hline & Mean & $\begin{array}{l}\text { Std. } \\
\text { Error }\end{array}$ & \begin{tabular}{|l} 
Pct. \\
Error
\end{tabular} & $\mathrm{N}$ & Mean & Std. Error & \begin{tabular}{|l|} 
Pct. \\
Error
\end{tabular} & $\mathrm{N}$ & Mean & $\begin{array}{l}\text { Std. } \\
\text { Error }\end{array}$ & \begin{tabular}{|l} 
Pct. \\
Error ${ }^{1}$
\end{tabular} & $\mathrm{~N}$ \\
\hline \multicolumn{13}{|c|}{ Per Party Trip Spending } \\
\hline Gas/oil auto & $\$ 11.24$ & $\$ 1.31$ & $12 \%$ & 201 & $\$ 13.63$ & $\$ 1.83$ & $13 \%$ & 161 & $\$ 2.50$ & $\$ 2.50$ & $100 \%$ & 2 \\
\hline Other expenses auto & $\$ 3.11$ & $\$ 2.04$ & $66 \%$ & 199 & $\$ 1.41$ & $\$ 0.49$ & $35 \%$ & 163 & $\$ 0.00$ & - & - & 2 \\
\hline Gas/oil boat & $\$ 27.03$ & $\$ 1.89$ & $7 \%$ & 200 & $\$ 32.10$ & $\$ 3.70$ & $12 \%$ & 160 & $\$ 33.00$ & $\$ 27.00$ & $82 \%$ & 2 \\
\hline Other expenses boat & $\$ 21.10$ & $\$ 7.39$ & $35 \%$ & 201 & $\$ 22.57$ & $\$ 7.69$ & $34 \%$ & 161 & $\$ 0.00$ & - & - & 2 \\
\hline Restaurants & $\$ 20.22$ & $\$ 2.36$ & $12 \%$ & 201 & $\$ 20.22$ & $\$ 2.48$ & $12 \%$ & 158 & $\$ 0.00$ & - & - & 2 \\
\hline Groceries & $\$ 37.33$ & $\$ 4.08$ & $11 \%$ & 198 & $\$ 33.81$ & $\$ 3.15$ & $9 \%$ & 160 & $\$ 50.00$ & $\$ 50.00$ & $100 \%$ & 2 \\
\hline Campground fees & $\$ 0.50$ & $\$ 0.26$ & $53 \%$ & 202 & $\$ 4.44$ & $\$ 2.34$ & $53 \%$ & 162 & $\$ 0.00$ & - & - & 2 \\
\hline Lodging & $\$ 0.64$ & $\$ 0.42$ & $65 \%$ & 202 & $\$ 0.03$ & $\$ 0.03$ & $100 \%$ & 162 & $\$ 0.00$ & - & - & 2 \\
\hline Recreation fees & $\$ 9.41$ & $\$ 2.14$ & $23 \%$ & 201 & $\$ 4.64$ & $\$ 1.13$ & $24 \%$ & 160 & $\$ 0.00$ & - & - & 2 \\
\hline Sporting goods & $\$ 13.72$ & $\$ 4.19$ & $31 \%$ & 201 & $\$ 3.40$ & $\$ 0.88$ & $26 \%$ & 161 & $\$ 0.00$ & - & - & 2 \\
\hline Other supplies & $\$ 14.75$ & $\$ 3.50$ & $24 \%$ & 200 & $\$ 14.53$ & $\$ 5.85$ & $40 \%$ & 161 & $\$ 2.50$ & $\$ 2.50$ & $100 \%$ & 2 \\
\hline Total within $\mathbf{3 0}$ miles & $\$ 159.04$ & & & & $\$ 150.78$ & & & & $\$ 88.00$ & & & \\
\hline Expenses $30+$ Miles $^{2}$ & $\$ 46.98$ & $\$ 6.58$ & $14 \%$ & 196 & $\$ 34.00$ & $\$ 3.93$ & $12 \%$ & 152 & $\$ 115.00$ & $\$ 85.00$ & $74 \%$ & 2 \\
\hline Total trip spending & $\$ 206.03$ & & & & $\$ 184.78$ & & & & $\$ 203.00$ & & & \\
\hline $\begin{array}{l}\text { Pct. of local spending } \\
\text { (within } 30 \text { miles) }\end{array}$ & $77 \%$ & & & & $82 \%$ & & & & $43 \%$ & & & \\
\hline \multicolumn{13}{|c|}{ Annual Spending } \\
\hline Storage fees & $\$ 110.16$ & $\$ 11.09$ & $10 \%$ & 182 & $\$ 148.60$ & $\$ 15.99$ & $11 \%$ & 160 & $\$ 100.00$ & - & - & 1 \\
\hline Insurance payments & $\$ 200.49$ & $\$ 11.96$ & $6 \%$ & 159 & $\$ 224.71$ & $\$ 12.31$ & $5 \%$ & 133 & $\$ 250.00$ & - & - & 1 \\
\hline Boat repair/maintenance & $\$ 185.83$ & $\$ 21.04$ & $11 \%$ & 179 & $\$ 278.61$ & $\$ 67.71$ & $24 \%$ & 155 & $\$ 0.00$ & - & - & 1 \\
\hline Dock maintenance/repair & $\$ 132.46$ & $\$ 30.24$ & $23 \%$ & 185 & $\$ 124.61$ & $\$ 27.02$ & $22 \%$ & 155 & $\$ 0.00$ & - & - & 1 \\
\hline $\begin{array}{l}\text { Cost of the boat (in } 1999 \\
\text { dollars) }\end{array}$ & $\$ 11,126.12$ & $\$ 503.94$ & $5 \%$ & 174 & $\$ 14,551.88$ & $\$ 1,151.73$ & $8 \%$ & 148 & $\$ 3063.91$ & - & - & 1 \\
\hline \multicolumn{13}{|c|}{ Visitor Characteristics } \\
\hline $\begin{array}{l}\text { Total trips using boat } \\
\text { (last year) }\end{array}$ & 40.00 & 3.70 & $9 \%$ & 187 & 35.94 & 3.38 & $9 \%$ & 156 & 76.00 & 24.00 & $32 \%$ & 2 \\
\hline $\begin{array}{l}\text { Nights away from home } \\
\text { (last trip) }\end{array}$ & 2.23 & 0.16 & $7 \%$ & 200 & 2.63 & 0.21 & $8 \%$ & 161 & 1.00 & 1.00 & $100 \%$ & 2 \\
\hline Days used boat (last trip) & 2.28 & 0.12 & $5 \%$ & 199 & 2.55 & 0.15 & $6 \%$ & 154 & 2.00 & 1.00 & $50 \%$ & 2 \\
\hline People on boat (last trip) & 4.50 & 0.22 & $5 \%$ & 201 & 5.40 & 0.30 & $6 \%$ & 162 & 3.00 & 1.00 & $33 \%$ & 2 \\
\hline
\end{tabular}




\section{Total spending}

The figures in Table 11 were derived from secondary data sources, the Natural Resource Management System (NRMS) (USACE 2006c) and from survey data for Rough River (e.g., average number of trips per household last year). Applying these figures, Rough River dock users took 44,063 boating party trips in 1999 (6.6 percent of total recreation use ${ }^{1}$ ) and purchased 61 new boats.

Table 11. Total annual use figures for community dock owner survey at Rough River Lake (1999).

\begin{tabular}{|l|r|l||}
\hline Category & $\begin{array}{l}\text { Total } \\
\text { Use }\end{array}$ & Computation Procedures \\
\hline Number of docks & 385 & From NRMS (1999) \\
\hline Number of boats & 1,597 & From NRMS (1999) \\
\hline $\begin{array}{l}\text { Average number of boats per } \\
\text { household }\end{array}$ & 1.36 & From this survey \\
\hline Number of households & 1,174 & $\begin{array}{l}\text { Total number of boats divided by average number of boats } \\
\text { per household }\end{array}$ \\
\hline Number of party trips & 44,063 & $\begin{array}{l}\text { Total party trips (from Table 3) times total number of } \\
\text { households (Reference Foreword) }\end{array}$ \\
\hline $\begin{array}{l}\text { Percent of new boats } \\
\text { purchased last year }\end{array}$ & $5.21 \%$ & $\begin{array}{l}\text { Computed from survey results, using the three-year } \\
\text { average (1997 to 1999) }\end{array}$ \\
\hline $\begin{array}{l}\text { Number of new boats } \\
\text { purchased last year }\end{array}$ & 61 & $\begin{array}{l}\text { Total households times percent of new boats purchased } \\
\text { last year }\end{array}$ \\
\hline
\end{tabular}

Local and total trip-related spending (Tables 12 and 13) is calculated by multiplying the number of party-trips in Table $11(44,063)$ by the trip spending averages in Table 8. Total spending on boats and fixed, annual goods and services (Table 14) is estimated by multiplying the number of households in Table 11 $(1,174)$ by the annual expenditures on boats, dock maintenance, and storage in Table 8. Total spending on insurance is estimated by multiplying the number of boats $(1,597)$ by the proportion of local boat dock owners who purchased boat insurance and their average insurance payment. Total spending on purchasing new boats is estimated by multiplying the number of new boats purchased last year (61) by the proportion of local dock owners who bought new boats and the average local new boat cost for three years: 1997-1999.

\footnotetext{
1 Two million recreation visits in 1999 from Table 1 divided by an average party size of 3.0 from Propst et al. (1998) equals 667,000 total party trips; 44,000 is 6.6 percent of 667,000 party trips.
} 
A recreation visit, as reported in the NRMS database, is one person entering a Corps project or lake boundary. Spending depends on how long people stay in the local region rather than how many times they enter the project or how much time they spend in recreation activities while there. Recreation visits are therefore converted to party trips ${ }^{1}$ in the region before applying spending averages. This procedure avoids double counting the spending of community dock users who may enter the project multiple times on the same day and also takes into account additional days a dock user may spend in the area outside the lake boundaries.

The estimated trip spending for all Rough River community dock users in 1999 was $\$ 6.65$ million spent within the local region (Table 12). If trip spending outside 30 miles is included, the total rises to $\$ 8.47$ million (Table 13). Only trip spending within 30 miles of the boat dock (\$6.65 million) should be included when conducting economic impact analysis at the project level (multi-county region).

Table 12. Total trip spending in local area ${ }^{1}$ by Rough River Lake community dock owners/users (1999).

\begin{tabular}{|l|l||}
\hline Spending Category & Spending (\$MM) \\
\hline \hline Gas/oil auto & $\$ 0.54$ \\
\hline Other expenses auto & $\$ 0.10$ \\
\hline Gas/oil boat & $\$ 1.26$ \\
\hline Other expenses boat & $\$ 0.90$ \\
\hline Food/drink restaurants & $\$ 0.90$ \\
\hline Groceries & $\$ 1.55$ \\
\hline Campground fees & $\$ 0.09$ \\
\hline Lodging & $\$ 0.02$ \\
\hline Recreation fees & $\$ 0.31$ \\
\hline Sporting goods & $\$ 0.38$ \\
\hline Other supplies & $\$ 0.62$ \\
\hline Total trip spending & $\$ 6.65$ \\
\hline \hline 1 Local trip spending equals spending within 30 & miles of the dock. \\
\hline \hline
\end{tabular}

\footnotetext{
1 See Table 11 for the conversion steps. A party is a travel group staying in the area (within 30 miles of the dock). The travel group is usually all individuals in the same vehicle or on the same boat or staying in the same room or campsite. During the interviews, community dock users were asked to report expenditures for their entire party for the last trip. Thus, the units for expenditures are party trips. Converting visits to party trips assures that the units are the same in the multiplication steps that lead to estimates of total expenditures (visits in party trips times expenditures in party trips).
} 
Table 13. Total trip spending ${ }^{1}$ by Rough River Lake community dock owners/users (1999)

\begin{tabular}{||l|l||}
\hline Spending Category & Spending (\$MM) $)^{2}$ \\
\hline \hline Gas/oil auto & $\$ 0.75$ \\
\hline Other expenses auto & $\$ 0.14$ \\
\hline Gas/oil boat & $\$ 1.26$ \\
\hline Other expenses boat & $\$ 0.90$ \\
\hline Food/drink restaurants & $\$ 1.27$ \\
\hline Groceries & $\$ 2.17$ \\
\hline Campground fees & $\$ 0.13$ \\
\hline Lodging & $\$ 0.02$ \\
\hline Recreation fees & $\$ 0.44$ \\
\hline Sporting goods & $\$ 0.53$ \\
\hline $\begin{array}{l}\text { Other supplies } \\
\text { Total trip spending }\end{array}$ & $\$ 0.87$ \\
\hline $\begin{array}{l}1 \text { Total trip spending equals spending within and outside 30 miles of the dock. } \\
\text { 2 Dock owners were asked to report trip spending outside 30 miles of the commu- } \\
\text { nity dock as one total amount, not broken down by item as this table shows. This } \\
\text { aggregate spending figure was then proportionally distributed into all but two cate- } \\
\text { gories based on the spending proportions within } 30 \text { miles. Proportional allocations } \\
\text { were not made to the "gas/oil boat" and "other expenses boat" categories. It was } \\
\text { assumed that, for these two categories, there were no boating expenditures outside } \\
\text { 30 miles of the community dock. }\end{array}$ \\
\hline
\end{tabular}

Fixed, annual goods and services related to boating activities in this study were new boats, dock repairs and maintenance, storage fees, insurance, and boat repairs and maintenance. Rough River's community dock owners spent \$1.1 million (1999 dollars) on boating-related annual goods and services (Table 14). Thirty-four percent of the money was spent on purchases of new boats $(\$ 360,000)$, followed by boat maintenance and repair $(\$ 260,000)$, insurance payments $(\$ 160,000)$, storage fees $(\$ 150,000)$, and dock maintenance $(\$ 140,000)$. 
Table 14. Total spending on fixed, annual goods and services by community dock owners at Rough River Lake (1999).

\begin{tabular}{|l|l||}
\hline Spending Category & Spending (\$MM) \\
\hline Storage fees & $\$ 0.15$ \\
\hline $\begin{array}{l}\text { Insurance payments (include only payments from boat dock } \\
\text { owners who lived within 30 miles of the community dock) }\end{array}$ & $\$ 0.16$ \\
\hline Boat repair/maintenance & $\$ 0.26$ \\
\hline Dock maintenance/repair & $\$ 0.14$ \\
\hline Purchases of new boats (within 30 miles) & $\$ 0.36$ \\
\hline Total durable goods spending & $\$ 1.07$ \\
\hline
\end{tabular}

\section{Economic impacts of community dock user spending}

\section{9 impacts}

The \$6.65 million in trip-related spending from Table 12 had a direct economic impact on the region of $\$ 3.5$ million in direct sales, $\$ 1.28$ million in personal income (wages and salaries), and supported 79 jobs in the region (Table 15). The retail sector received the largest amount of direct sales ( $\$ 1.1$ million) followed by the eating and drinking (restaurants and bars) sector $(\$ 900,000)$.

Direct effects are less than total spending, as only the retail and wholesale margins on visitor purchases of goods accrue to the local economy. The local region surrounding Rough River Lake captures 53 percent of dock user spending. Forty-seven percent leaks out of the local economy to cover the costs of imported goods bought by visitors. ${ }^{1}$

The sales multiplier ${ }^{2}$ for the region is 1.37 , meaning that an additional $\$ 0.37$ in sales is generated through secondary effects for every dollar of direct sales. Secondary effects generate an additional 18 jobs, for a total of 97 direct and secondary jobs (Table 15). Likewise, secondary effects generate an additional \$430,000 in personal income and \$730,000 in value added (personal income + proprietor's income + indirect business tax).

1 For example, if a visitor buys $\$ 50$ worth of clothing that is not manufactured in the local region, only the local margins (retail and locally operated wholesale and transportation), say, $\$ 30$, will be captured by the local economy as direct sales. The remaining $\$ 20$ will leak immediately outside the local economy to cover the producer price (or price of good at the factory), and non-local margins (wholesale and transportation).

2 Multipliers for the 6-county region are from a 2000 input-output model estimated with the IMPLAN system. 
Table 15. Regional economic impacts of Rough River Lake community dock owners'/users' trip spending (1999, for trip spending within 30 miles only).

\begin{tabular}{|c|c|c|c|c|}
\hline \multicolumn{5}{|c|}{$\begin{array}{l}\text { Summary Results Table } \\
\text { Impacts on Local Economy }\end{array}$} \\
\hline Economic Measure & & Direct & Multiplier & Total \\
\hline Output/Sales (\$MM) & & $\$ 3.50$ & 1.37 & $\$ 4.80$ \\
\hline Total Income (\$MM) & & $\$ 1.28$ & 0.49 & $\$ 1.71$ \\
\hline Total Value added (\$MM) & & $\$ 1.92$ & 0.76 & $\$ 2.65$ \\
\hline Jobs & & 78.92 & 27.69 & 97.00 \\
\hline Total Visitor Spending ( $\$ \mathrm{MM})$ & & & 6.65 & \\
\hline Capture rate & & & $53 \%$ & \\
\hline Effective spending multiplier & & & 0.72 & \\
\hline \multicolumn{5}{|c|}{ Direct Effects } \\
\hline Sector & Sales (\$MM) & Income (\$MM) & Value Added (\$MM) & Jobs \\
\hline Lodging & $\$ 0.11$ & $\$ 0.04$ & $\$ 0.06$ & 3.00 \\
\hline Eat \& drink & $\$ 0.90$ & $\$ 0.32$ & $\$ 0.45$ & 28.41 \\
\hline Amusement and recreation & $\$ 0.13$ & $\$ 0.05$ & $\$ 0.08$ & 6.51 \\
\hline Retail & $\$ 1.07$ & $\$ 0.52$ & $\$ 0.85$ & 27.79 \\
\hline Wholesale & $\$ 0.20$ & $\$ 0.08$ & $\$ 0.14$ & 2.69 \\
\hline Other services & $\$ 0.31$ & $\$ 0.07$ & $\$ 0.11$ & 2.89 \\
\hline Groceries & $\$ 0.07$ & $\$ 0.01$ & $\$ 0.02$ & 0.41 \\
\hline Sporting goods & $\$ 0.01$ & $\$ 0.00$ & $\$ 0.00$ & 0.00 \\
\hline Other manufacturing & $\$ 0.62$ & $\$ 0.17$ & $\$ 0.20$ & 6.71 \\
\hline Government & $\$ 0.08$ & $\$ 0.02$ & $\$ 0.02$ & 0.52 \\
\hline Total & $\$ 3.50$ & $\$ 1.28$ & $\$ 1.92$ & 78.92 \\
\hline \multicolumn{5}{|c|}{ Total Effects } \\
\hline Sector & Sales (\$MM) & Income (\$MM) & Value Added (\$MM) & Jobs \\
\hline Lodging & $\$ 0.12$ & $\$ 0.04$ & $\$ 0.07$ & 3.20 \\
\hline Eat \& drink & $\$ 0.95$ & $\$ 0.33$ & $\$ 0.47$ & 29.96 \\
\hline Amusement and recreation & $\$ 0.14$ & $\$ 0.06$ & $\$ 0.08$ & 6.71 \\
\hline Retail & $\$ 1.18$ & $\$ 0.58$ & $\$ 0.94$ & 30.89 \\
\hline Wholesale & $\$ 0.26$ & $\$ 0.11$ & $\$ 0.18$ & 3.51 \\
\hline Other services & $\$ 1.04$ & $\$ 0.30$ & $\$ 0.55$ & 11.78 \\
\hline Groceries & $\$ 0.11$ & $\$ 0.02$ & $\$ 0.02$ & 0.62 \\
\hline Sporting goods & $\$ 0.01$ & $\$ 0.00$ & $\$ 0.00$ & 0.00 \\
\hline Other manufacturing & $\$ 0.87$ & $\$ 0.24$ & $\$ 0.30$ & 9.19 \\
\hline Government & $\$ 0.13$ & $\$ 0.03$ & $\$ 0.04$ & 1.14 \\
\hline Total & $\$ 4.80$ & $\$ 1.71$ & $\$ 2.65$ & 97.00 \\
\hline
\end{tabular}


Roughly 12 direct jobs are supported by each million dollars in total dock user spending. Including multiplier effects, each million dollars in total dock user spending supports about 15jobs.

The \$1.1 million in spending on new boats, storage fees, insurance, and repairs/maintenance from Table 14 had a direct economic impact on the region of $\$ 620,000$ in direct sales, $\$ 150,000$ in personal income (wages and salaries), and supported six direct jobs in the region (Table 16). The other services sector received the largest amount of direct sales $(\$ 300,000)$, followed by other manufacturing $(\$ 210,000)$.

Direct effects only accrue to the industries where dock owner spending is directly received. For example, since no money is spent in the Eat \& Drink sector from dock owner annual or durable goods spending, that cell is blank in the top sector of Table 16 (direct effects). However, other companies receiving direct payments, e.g., insurance companies, may hire employees who live in the region and spend money in the local Eat \& Drink sector. Since this is a multiplier (secondary) effect, some amount of sales appears in the Eat \& Drink cell in the total effects sector of Table 16.

The local region surrounding Rough River Lake captures 58 percent of dock owner spending on new boats and annual services. Forty-two percent leaks out of the local economy to cover the costs of imported boats and services bought by visitors.

The sales multiplier for the region is 1.38 , meaning that an additional $\$ 0.38$ in sales is generated through secondary effects for every dollar of direct sales. Secondary effects generate an additional 2.9 jobs, for a total of 8.5 direct and secondary jobs (Table 16). Likewise, secondary effects generate an additional $\$ 70,000$ in personal income and $\$ 120,000$ in value added (personal income + proprietor's income + indirect business tax). Roughly 5.2 direct jobs are supported by each million dollars in total community dock owner spending for new boats and annual services. Including multiplier effects, each million dollars in total dock owner spending supports about eight jobs. 
Table 16. Regional economic impacts of Rough River Lake community dock owners' durable goods and annual spending (1999).

\begin{tabular}{|c|c|c|c|c|}
\hline \multicolumn{5}{|c|}{$\begin{array}{l}\text { Summary Results Table } \\
\text { Impacts on Local Economy }\end{array}$} \\
\hline Economic measure & & Direct & Multiplier & Total \\
\hline Output/Sales (\$MM) & & $\$ 0.62$ & 1.38 & $\$ 0.86$ \\
\hline Total Income (\$MM) & & $\$ 0.15$ & 0.36 & $\$ 0.22$ \\
\hline Total Value added (\$MM) & & $\$ 0.21$ & 0.54 & $\$ 0.33$ \\
\hline Jobs & & 5.58 & 13.66 & 8.47 \\
\hline Total Visitor Spending (\$MM) & & & 1.07 & \\
\hline Capture rate & & & $58 \%$ & \\
\hline Effective spending multiplier & & & 0.80 & \\
\hline \multicolumn{5}{|c|}{ Direct Effects } \\
\hline Sector & Sales (\$MM) & Income (\$MM) & Value Added (\$MM) & Jobs \\
\hline Lodging & $\$-$ & $\$-$ & $\$-$ & - \\
\hline Eat \& drink & $\$-$ & $\$-$ & $\$-$ & - \\
\hline Amusement and recreation & $\$-$ & $\$-$ & $\$-$ & - \\
\hline Retail & $\$ 0.10$ & $\$ 0.04$ & $\$ 0.07$ & 1.86 \\
\hline Wholesale & $\$ 0.01$ & $\$ 0.00$ & $\$ 0.01$ & 0.10 \\
\hline Other services & $\$ 0.30$ & $\$ 0.04$ & $\$ 0.07$ & 1.55 \\
\hline Groceries & $\$-$ & $\$-$ & $\$-$ & - \\
\hline Sporting goods & $\$-$ & $\$-$ & $\$-$ & - \\
\hline Other manufacturing & $\$ 0.21$ & $\$ 0.06$ & $\$ 0.07$ & 2.07 \\
\hline Government & $\$ 0.00$ & $\$ 0.00$ & $\$ 0.00$ & 0.00 \\
\hline Total & $\$ 0.62$ & $\$ 0.15$ & $\$ 0.21$ & 5.58 \\
\hline \multicolumn{5}{|c|}{ Total Effects } \\
\hline Sector & Sales (\$MM) & Income (\$MM) & Value Added (\$MM) & Jobs \\
\hline Lodging & $\$ 0.00$ & $\$ 0.00$ & $\$ 0.00$ & 0.00 \\
\hline Eat \& drink & $\$ 0.01$ & $\$ 0.00$ & $\$ 0.00$ & 0.21 \\
\hline Amusement and recreation & $\$ 0.00$ & $\$ 0.00$ & $\$ 0.00$ & 0.00 \\
\hline Retail & $\$ 0.11$ & $\$ 0.05$ & $\$ 0.08$ & 2.27 \\
\hline Wholesale & $\$ 0.02$ & $\$ 0.01$ & $\$ 0.01$ & 0.21 \\
\hline Other services & $\$ 0.44$ & $\$ 0.09$ & $\$ 0.15$ & 3.20 \\
\hline Groceries & $\$ 0.00$ & $\$ 0.00$ & $\$ 0.00$ & 0.00 \\
\hline Sporting goods & $\$ 0.00$ & $\$ 0.00$ & $\$ 0.00$ & 0.00 \\
\hline Other manufacturing & $\$ 0.26$ & $\$ 0.07$ & $\$ 0.08$ & 2.48 \\
\hline Government & $\$ 0.01$ & $\$ 0.00$ & $\$ 0.00$ & 0.10 \\
\hline Total & $\$ 0.86$ & $\$ 0.22$ & $\$ 0.33$ & 8.47 \\
\hline
\end{tabular}




\section{Value of 1999 impacts in 2004 dollars}

The 1999 economic impacts reported above were adjusted to 2004 impacts by multiplying 1999 figures by an average consumer price index of 1.21 (U.S. Department of Labor 2006). Results are presented in Table 17.

Table 17. Regional economic impacts of Rough River Lake community dock owners'/users' trip and owners' annual spending (in 2004 dollars, for spending within 30 miles only).

\begin{tabular}{||l|l|l|l|l||}
\hline \multicolumn{2}{||}{ Economic Impact } & \multicolumn{2}{l||}{$\begin{array}{l}\text { Trip Spending (within } \\
30 \text { miles) }\end{array}$} & $\begin{array}{l}\text { Durable Goods and other Annual Costs Spent } \\
\text { Locally }\end{array}$ \\
\hline \hline Total spending $(\$ M M)$ & $\$ 8.05$ & $\$ 1.29$ & Total Effects \\
\hline & Direct Effects & Total Effects & Direct Effects & $\$ 1.04$ \\
\hline Output/sales $(\$ M M)$ & $\$ 4.24$ & $\$ 5.81$ & $\$ 0.75$ & $\$ 0.27$ \\
\hline Total income $(\$ M M)$ & $\$ 1.55$ & $\$ 2.07$ & $\$ 0.18$ & $\$ 0.40$ \\
\hline $\begin{array}{l}\text { Total value added } \\
(\$ M M)\end{array}$ & $\$ 2.33$ & $\$ 3.21$ & $\$ 0.26$ & \\
\hline \hline
\end{tabular}

In 2004 dollars, total community dock user trip spending locally of $\$ 8.05$ million resulted in $\$ 1.55$ million in the region in personal income and $\$ 2.33$ million in value added (personal income + proprietor's income + indirect business tax).With secondary (multiplier) effects, total impacts locally were $\$ 2.07$ million in personal income and $\$ 3.21$ million in value added. There is no change to the number of direct jobs (85) in going from Tables 15 and 16 to Table 17. This is because no new expenditures by dock users are being estimated in Table 17. Instead, expenditures from the 1999 survey are being inflated to 2004 dollars. Since there are no new expenditures, no additional jobs were created in 2004.

After converting annual goods and services to 2004 dollars, the results are $\$ 1.29$ million in community dock owner spending on new boats, storage fees, insurance, and repairs/maintenance. The impacts of annual spending include \$180,000 in personal income and \$260,000 in value added. With secondary (multiplier) effects, total impacts locally were $\$ 270,000$ in personal income and $\$ 400,000$ in value added. 


\section{Study Limitations and Error}

The accuracy of the estimates in this report rests on the three inputs: visits, spending averages, and multipliers. The number of trips reported by the sample of community dock owners and the number of boats at the docks are likely the largest potential sources of error.

The multipliers and economic ratios used to convert spending to jobs and income and to estimate secondary effects come from an IMPLAN model for the six-county region. Although it is difficult to estimate the levels of error, multipliers can vary by about 10 percent between different modeling systems. Multipliers largely influence estimates of secondary effects.

Depending on the direction and magnitude of errors in visits, spending, and multipliers, the various errors may compound or cancel each other. The most important potential errors are in the estimates of total trips. As the model is linear, doubling the amount of visitation will double spending and economic impacts.

In addition to these issues, there are also conceptual issues regarding how much and which spending may be claimed by the project. It is not simple to determine if users of community-owned docks would spend their money elsewhere if community docks were not available at Rough River Lake. Furthermore, local visitors are usually excluded in estimating economic impacts, but have been included here. Since they are not a distinct segment, their contribution to the total effects is not readily estimated. However, 44 percent of the dock owners interviewed stated that their permanent residences were within 30 miles of the project. Since approximately 79 percent of total trip spending occurred within 30 miles of the project, the impact of local spending cannot be ignored.

Only new boat purchases within 30 miles of the project are counted in this analysis. Further, it is assumed that dock maintenance fees and storage fees go primarily to local businesses. However, dock owners were not asked to identify the locations of their insurance companies or boat repair shops. Thus, the extent to which these expenditures accrue to the local economy is not known, but they have been counted as occurring locally (within the six-county region). 


\section{Summary and Discussion}

Users of community-owned docks at Rough River Lake spent \$6.7 (\$8.1) ${ }^{1}$ million in trip-related expenditures and \$1.1 (\$1.3) million in purchases of new boats and annual services within 30 miles of the lake in 1999. Combining both trip-related and durable expenditures, the direct economic effects of dock user spending were $\$ 4.1$ (\$5.0) million in sales, \$1.4 (\$1.7) million in personal income, and \$2.1 (\$2.6) million in direct value added. With multiplier effects, created by the recirculation of the money spent by dock users, visitor spending generated a total (direct + secondary) of \$5.7 (\$6.9) million in local sales, and an associated $\$ 1.9$ (\$2.3) million in personal income, and \$3.0 (\$3.6) million in value added. Sectors receiving the greatest benefit from community dock users were retail, food and drink, manufacturing, and other services. The $\$ 4.1$ million in direct sales is about 2.6 percent of the total of all tourism activity (163 million) (sales have been price inflated for this computation).

Total economic impacts (Tables 15, 16, and 17) are useful for accountability purposes, lake support, and explaining the role of the lake in the region's economy. The REAS model results can also be used to evaluate management alternatives and strategies and to conduct sensitivity analyses. The marginal economic impacts of particular visitor segments are useful for evaluating particular actions. Table 18 shows the changes in sales, jobs, income, and valued added associated with an increase or decrease of 1,000 additional party-trips by each segment. Marginal impact analysis provides answers to the question: "What if?" (Reference Foreword.)

For example, to evaluate the regional economic impacts of adding 27 docks, first compute the change in party trips - 10 docks produce 375 party trips (average of 37.5 trips per dock per year from Table 3 times 10 docks). That means 27 new docks would produce about 1,000 extra party trips per year. Applying the average spending for the overnight segment in Table 9, the expansion generates an additional $\$ 168,000$ in total trip spending ( $\$ 168$ per party trip from Table 9 times 1,000 ), $\$ 88,700$ in direct sales in the region, $\$ 32,500$ in personal income, $\$ 48,700$ in value added, and two jobs in direct effects (computed from

\footnotetext{
1 Numbers in parentheses are in 2004 dollars (see Table 17).
} 
ratios in Table 15). In 2004 dollars, the extra 1,000 party trips per year by community dock users would result in $\$ 107,400$ in direct sales in the region and $\$ 39,400$ in direct personal income. ${ }^{1}$ The impact of this alternative could be compared to others.

Table 18. Direct impacts of an additional 1,000 community dock owner party trips by segment, Rough River Lake.

\begin{tabular}{|c|c|c|c|c|c|}
\hline Segments & Local Spending (\$) & Direct Sales (\$) & Personal Income (\$) & Value Added (\$) & Jobs \\
\hline \multicolumn{6}{|c|}{ (Marginal impacts per 1,000 party-trips, in 1999 dollars) } \\
\hline Day use & $\$ 96,514$ & $\$ 50,836$ & $\$ 18,645$ & $\$ 27,893$ & 1.1 \\
\hline Overnight stay & $\$ 168,461$ & $\$ 88,732$ & $\$ 32,544$ & $\$ 48,686$ & 2.0 \\
\hline Small boat & $\$ 159,044$ & $\$ 83,772$ & $\$ 30,725$ & $\$ 45,965$ & 1.9 \\
\hline Medium boat & $\$ 150,782$ & $\$ 79,420$ & $\$ 29,129$ & $\$ 43,577$ & 1.8 \\
\hline Large boat & $\$ 88,000$ & $\$ 46,352$ & $\$ 17,000$ & $\$ 25,433$ & 1.0 \\
\hline \multicolumn{6}{|c|}{ (Marginal impacts per 1,000 party-trips, in 2004 dollars) } \\
\hline Day use & $\$ 116,783$ & $\$ 61,512$ & $\$ 22,560$ & $\$ 33,751$ & 1.1 \\
\hline Overnight stay & $\$ 203,838$ & $\$ 107,366$ & $\$ 39,378$ & $\$ 58,911$ & 2.0 \\
\hline Small boat & $\$ 192,443$ & $\$ 101,364$ & $\$ 37,177$ & $\$ 55,618$ & 1.9 \\
\hline Medium boat & $\$ 182,446$ & $\$ 96,099$ & $\$ 35,246$ & $\$ 52,728$ & 1.8 \\
\hline Large boat & $\$ 106,480$ & $\$ 56,085$ & $\$ 20,570$ & $\$ 30,774$ & 1.0 \\
\hline
\end{tabular}

The economic impacts presented in this report document the economic significance of 44,063 community dock user trips at Rough River Lake in 1999. The impacts will vary from year to year with changes in prices, visitor volumes, the mix of visitors attracted, and other changes in the lake and surrounding communities. The REAS model has built-in procedures to price-adjust spending averages over time, so updated figures may be obtained fairly easily, as done in this report, if there are not significant changes in visitor use and spending patterns. In the absence of significant structural changes in the local economy, multipliers will be quite stable. The primary input for updating the estimates is visitation, which must take into account any changes in the mix of visitors or their length of stay in the area.

\footnotetext{
1 The number of jobs, 2.0, remains the same in 2004 because Table 18 reflects the marginal impacts of 1,000 additional party trips; since the ratio between sales and jobs remains the same between 1999 and 2004 , the number of jobs per 1,000 additional party trips does not change.
} 


\section{References}

Chang, W. H., D. B. Propst, D. J . Stynes, and R. S. J ackson. 2003. Recreation visitor spending profiles and economic benefit to Corps of Engineers (CE) projects. Technical Report ERDC/EL TR-03-21. Vicksburg, MS: U.S. Army Engineer Research and Development Center.

Chang, W. H., D. J. Stynes, R. S. J ackson, and D. B. Propst. 2001. U.S. Army Corps of Engineers Recreation Economic Assessment System (REAS). Poster presentation. Portland, OR: National Natural Resources Management Conference, 2001.

Institute for Water Resources (IWR). 2006. OMB approved surveys. IWR Website. Stuart Davis, Subject Matter Expert, IWR, http:// www.waterresources.us/inside/ products/pub/surveyssearch.cfm?topic_Recreation (accessed J uly 10, 2006).

Minnesota IMPLAN Group, Inc. 1996. IMPLAN Professional social accounting \$ impact analysis software: User's guide. Stillwater, MN: Minnesota IMPLAN Group, Inc.

Minnesota IMPLAN Group. 2000. IMPLAN professional software, analysis and data guide, 2nd ed., Stillwater, MN: Minnesota IMPLAN Group, Inc.

Propst, D. B., D. J . Stynes, W. H. Chang, and R. S. J ackson. 1998. Estimating thelocal economic impacts of recreation at Corps of Engineers projects -- 1996. Technical Report R-98-1. Vicksburg, MS: U.S. Army Engineer Waterways Experiment Station.

U.S. Army Corps of Engineers. 1999. Project operation - Shoreline management at Civil Works projects. Engineer Regulation 1130-2-406. Washington, DC.

U.S. Army Corps of Engineers. 2006a. Economic Impact Analysis. Natural Resources Management Gateway, Wen-Huei Chang, Subject Matter Expert, CEERD-EE-E, http:/ / www.CorpsLakes.us/ REAS (accessed J uly 10, 2006).

U.S. Army Corps of Engineers. 2006b. Wildlife/ Natural Resource Management. Rough River Website. http:/ / 155.80.93.250/ rrl/ (accessed J uly 10, 2006).

U.S. Army Corps of Engineers. 2006c. Natural Resources Management System (NRMS) Historical Data. Natural Resources Management Gateway, Mike Owen, Subject Matter Expert, CESWF-OD-R, http://CorpsLakes.usace.army.mil/ employees/nrms/nrms.html (accessed J uly 10, 2006).

U.S. Census Bureau. 2006. State and County Quickfacts. http:// quickfacts.census.gov/ qfd/ index.html (accessed April 25, 2006).

U.S. Department of Labor. 2006. Bureau of Labor Statistics. average from 1999-2004, http://stats.bls.gov (accessed April 25, 2006). 


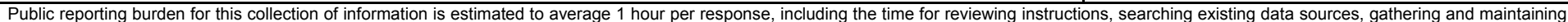

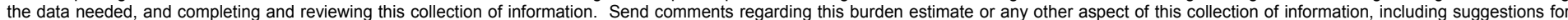

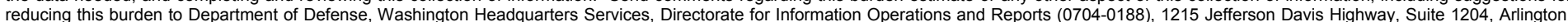

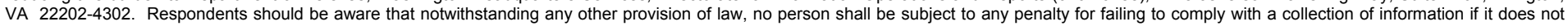
display a currently valid OMB control number. PLEASE DO NOT RETURN YOUR FORM TO THE ABOVE ADDRESS.

\begin{tabular}{l|c}
$\begin{array}{l}\text { 1. REPORT DATE (DD-MM-YYYY) } \\
\text { January } 2008\end{array}$ & $\begin{array}{c}\text { 2. REPORT TYPE } \\
\text { Final report }\end{array}$ \\
\hline
\end{tabular}

\section{TITLE AND SUBTITLE}

Economic Impacts from Spending by Community Dock Owners at Rough River Lake

3. DATES COVERED (From - To)

5a. CONTRACT NUMBER

5b. GRANT NUMBER

5c. PROGRAM ELEMENT NUMBER

5d. PROJECT NUMBER

5e. TASK NUMBER

5f. WORK UNIT NUMBER

8. PERFORMING ORGANIZATION REPORT NUMBER

ERDC/EL TR-08-3

U.S. Army Engineer Research and Development Center, Environmental Laboratory, 3909 Halls Ferry Road, Vicksburg, MS 39180-6199;

Michigan State University, 115 Natural Resources Building, East Lansing, MI 48824

9. SPONSORING / MONITORING AGENCY NAME(S) AND ADDRESS(ES)

10. SPONSOR/MONITOR'S ACRONYM(S)

U.S. Army Corps of Engineers

Washington, DC 20314-1000

11. SPONSOR/MONITOR'S REPORT NUMBER(S)

\section{DISTRIBUTION / AVAILABILITY STATEMENT}

Approved for public release; distribution is unlimited.

\section{SUPPLEMENTARY NOTES}

\section{ABSTRACT}

This report documents the local economic impacts of users of community-owned docks at Rough River Lake, located in western Kentucky. This economic assessment is based on the results of a 1999 survey of a sample of Rough River Lake community dock owners. Spending estimates are adjusted to 2004 dollars. The economic impacts estimated for Rough River Lake are useful for accountability purposes, lake support, and explaining the role of the lake in the region's economy. This report demonstrates how the survey results can be used to evaluate management alternatives and strategies and to conduct sensitivity analyses.

\section{SUBJECT TERMS}

Community dock owners

Community-owned docks

16. SECURITY CLASSIFICATION OF:

a. REPORT

UNCLASSIFIED

b. ABSTRACT
UNCLASSIFIED

Economic assessment Rough River Lake

c. THIS PAGE

UNCLASSIFIED
17. LIMITATION OF ABSTRACT

\begin{tabular}{|c|} 
18. NUMBER \\
OF PAGES \\
\cline { 2 - 2 } 46
\end{tabular}

19a. NAME OF RESPONSIBLE PERSON

19b. TELEPHONE NUMBER (include area code) 